\title{
DE GROOTE BANTAMSCHE OPSTAND IN HET MIDDEN DER VORIGE EEUW,
}

bewerkt naar meerendeels onuitgegeven bescheiden uit het oud-kolonianl archief met drie officiëele documenten als bijlagen.

DOOR

\section{P. J. B. C. ROBIDÉ VAN DER AA.}

Reeds van de zeventiende eeuw dagteekent in NederlandschIndië het voorschrift, dat de hoofden van gewestelijk bestuur, die als Gouverneur, Directeur, Commandeur, of onder welken geringeren titel ook, de verschillende kantoren der Oost-Indische Compagnie beheerden, bij de overgave van het bewind aan hunne opvolgers een Memorie tot Naricht moesten nalaten, waarin de stand van zaken in het door hen te verlaten gewest beknoptelijk, maar zakelijk beschreven werd. Vele dier ambtenaren konden aan dit voorschrift niet voldoen, omdat zij op hun post overleden of zwaar ongesteld vertrokken; andere hebben, om welke reden dan ook, dien plicht geheel verzuimd, terwijl sommige dier Memoriën van Overgave van te weinig belang waren, om in later dagen nog de aandacht te verdienen. Daarentegen bestaat er van bijzonder kundige en ijverige hoofdambtenaren een aantal van zulke Memoriën van zoo zaakrijken inhoud, dat zij jaren achtereen hunnen opvolgers tot vraagbaak en richtsnoer strekten en ook nu nog een groot gewicht voor de geschiedenis onzer overzeesche gewesten behouden hebben. Daartoe behooren de hier voor het eerst uit het Koloniaal Archief uitgegeven Memoriën betrekkelijk Bantam, waarvan de eerste werd opgesteld door den lateren Directeur-Generaal Julius Valentijn Stein van Gollenesse, toen hij in 1734 als Gezaghebber aldaar aftrad, de tweede vervaardigd is door den lateren Raad van Indië Willem Hendrik van Ossenberch, toen deze in 1761 als Commandeur van Bantam het bewind aan zijn opvolger Hugo Pieter Faure overdroeg. 
In den laatsten tijd is onze kemnis der inwendige geschiedenis van het Bantamsche Rijk gedurende de eerste zestig jaren der vorige eeuw aanzienlijk vermeerderd door hetgeen de zoo ontijdig aan de wetenschap ontrukte Jhr. mr. J. K. J. de Jonge dienaangaande heeft in het licht gegeven in de drie laatste deelen der met rusteioozen arbeid bijeengebrachte bronnenverzameling: De Opkomst van het Nederlandsch gezag in OostIndië. Over dit lange tijdperk bepalen de mededeelingen van den terecht zoo algemeen betreurden Schrijver zich echter hoofdzakelijk tot hetgeen de Hooge Indische Regeering omtrent de zaken van Bantam in hare Algemeene Brieven aan Bewindhebbers opnam. Behalve het hoogst belangrijke Rapport van den lateren Gouverneur-Generaal Mossel over zijne zending naar het Bantamsche Hof in 1747 (D. X, bl. 115-124) vindt men daar geen eenigszins uitvoerig stuk, waarin de oogenblikkelijke toestand in het rijk van Bantam meer omstandig door een ooggetuige beschreven is. Daarom is de uitgave der hier nu volgende Memoriën van (Overgave van Gollenesse en van Oscenberch niet overbodig, dewijl zij ons den staat van zaken in Bantam dertien jaar vóór en veertien jaar na Mossels verslag nauwkeurig doen kennen. Vooral is dit het geval met het oudste dier beide stukken wegens de gewichtige mededeelingen, die het bevat over de afkomst der beruchte Ratoe Sjariefa en over den oorsprong van haren voor de macht der Bantamsche Sultans zoo noodlottigen invloed. Tot juister verstand van dit gewicht zal het niet ondienstig zijn, hier eenigszins uitvoerig te beschrijven, hoe het drijven dezer heerschzuchtige vrouw in den herfst van 1750 den geweldigen opstand verwekte, waardoor het eens zoo machtige Bantam van een tot dusver alleen door exclusieve tractaten van monopolie aan de Compagnie verbonden rijk in een geheel afhankelijken leenstaat herschapen werd.

Sultan Aboe'l Fath Mohammed Sjafeі Zeinoe'l Arifien, wiens grillig en wispelturig karakter ons hierachter door Golienesses vaardige pen zoo duidelijk beschreven wordt, zag in het laatst der zeventiende eeuw het levenslicht. Als de jongere zoon van Sultan Zeinoe'l Abedien en diens geliefde gemalin Ratoe Anum, evenals haar gemal een kleinkind van den beroemden Sultan Agong, kreeg hij eerst in 1723 door den moord op ziju vijftien jaar te voren tot Kroomprins erkenden broeder Mohammed Salee uitzicht op den troon van Bantam. Het duurde echter tot 1731, eer zijn vader, door een beroerte aan de 
noodzakelijkheid herinnerd, om de opvolging in zijn rijk te regelen, hem als Kroonprins aan de Indische Regeering voordroeg, welke toen den Raad van Indië Michiel Westpalm in bỵzondere zending naar Bantam afvaardigde, om haar bij de plechtigheid der installatie te vertegenwoordigen. Reeds voor zijne verheffing tot deze hooge waardigheid moet de prins, die destijds Rana Mangala genoemd werd, zijn levenslot verbonden hebben aan de merkwaardige vrouw, die als Ratoe Sjariefa Fatima in de geschiedenis bekend staat. Uit Gollenesses Memorie leert men - en dit bevestigt ten volle de vernuftige gissing, die Prof. Veth (Java, D. II, bl. 494) uit haar naam afleidde - dat zij de dochter was van een Arabisch priester, die zich met al zijne kinderen door het voeren van den titel van Sjarief als een afstammeling van den Profeet deed gelden. Door dezen in het oog van den geloovigen Muzelman bijna goddelijken oorsprong, door hare Arabische afkcmst, door haar vorig verblijf te Batavia, niet minder door haren daar, naar het schijnt, zeer vertrouwelijken omgang met honggeplaatste Europeanen, en vooral door hare dientengevolge ver boven de meeste inlandsche vrouwen uitblinkende beschaving en wereldwijsheid, verkreeg Ratoe Sjariefa in Bantam, nog bij het leven van den ouden Sultan, een invloed, dien men slechts bij dien harer schoone tijdgenoote aan het Hof van Versailles, de Markiezin de Pompadour, kan vergelijken. Wisten wij slechts met rekerheid, of zij reeds in 1723 aan het Bantamsche Hof verbouden was, dan zoude het ons zelfs niet verbazen, dat de moordaanslag op den vorigen Kroonprins en diens broeder door haar was bewerkt. Met levendige kleuren schildert ons Gollenesse, hoezeer haar invloed gestegen was, reeds gedurende het eerste jaar der regeering van haar gemaal, die in 1733 zijn vader opvolgde, en hoe zij, welke vrouweu de vorst ook nevens haar in zijn harem opnam, den titel van Ratoe Sultan of Koningin uitsluitend voor zich behield. Trachtte zij destijds diens voorzoon Pangéran Arief, den eenigen mamnelijken telg uit een vorstelijk huwelijk, te koppelen an de dochter van een harer broeders, elf jaar later wist zij door hare intrigues vader en zoon zoozeer van elkander te verwijderen, dat de laatste met andere prinsen van zijn aanhang naar Batavia de vlucht nam en eindelijk naar Ceilon verbannen werd. Tevens haalde zij den zwakken Sult:m Zeinoe'| Arifien over, in diens pla ts tot troonopvolger te kiezen haar neef, den met zijue 
dochter uit een andere vrouw gehuwden Sjarief Abdoella Mohammed Sjafeï, door welke schikking de kroon uit het aloud geslacht der Bantamsche vorsten in de familie van Ratoe Sjariefa zou overgaan 1.

Het moet erkend worden, dat de Indische Regeering eerst na zeer langdurige aarzeling hare goedkeuring hechtte aan zulk een gewelddadigen ommekeer, zoo geheel in strijd met den aard en de begrippen der gemeenlijk zeer an hare oude vorstenhuizen gehechte inlandsche bevolking. Hoezeer de Sultan van Bantam reeds in den loop van 1745, toen zijn zoon naar Batavia vluchtte, op de erkenning van den Sjarief als troonsopvolger aandrong, vertrok de Directeur-Generaal Mossel eerst in het begin van 1747 naar Bantam, om de installatie van den nieuwen Kroonprins bij te wonen, terwijl de naar Batavia uitgeweken prinsen niet voor het laatst van dat jaar en niet dan op den herhaalden aandrang des Sultans naar Ceilon verzonden werden. Troostte Mossel, die in den Raad van Indië het langst de rechten, der legitimiteit verdedigd had, zich bij het stellen van zijn Rapport met de overweging, dat Ratoe Sjariefa "soolange zij leeft, apparent wel alles na hare geneygd"heyt sal schicken, als politie genoeg besittende, om haren "man in te nemen en sig wel te doen bedienen," reeds in den loop van het volgende jaar ontstond er nieuwe verwarring aan het Bantamsche Hof, doordat zich bij den Sultan Zeinoe'l Arifien de beginselen openbaarden eener, naar het schijnt, van zijn vader overgeërfde hersenkwaal, die dezen Oosterschen despoot tot de grootste gruwelen en wreedheden dreef. Minder gegrond schijnt mij het somtijds uitgesproken vermoeden, dat de waanzin des Sultans zou voortspruiten uit eenig toegediend vergif, dat dan moest geschied zijn door Ratoe Sjariefa, om na den dood haar gemaals voor zich alleen de oppermacht in Bantam te verwerven. Veeleer houd ik met de Indische Regeering den zonderlingen geestestoestand van den vorst ontstaan uit de wet der erfelijkheid, terwijl het zeer verklaarbaar is, dat

1 J. de Rovere van Breugel noemt ten onrechte in zijne belangrijke Bedenkingen over den staat van Bantam in 1786 (zie deze Bijdragen, N. R., D. I, bl. 112 en 316) Pangéran Sjarief een eigen voorzoon van Ratoe Sjariefa, welke vorstin, evenals vele vrouwen van har slag, waarschijnlijk steeds kinderloos bleef. Ook de Jonge vergistte zich in dit opzicht (D. X, bl. XLIX). De ware verhonding van dezen prins tot den Sultan en diens gemalin blijkt duidelijk uit het Rapport van Mossel (aldaar bl. 119) en uit andere officiëele bescheiden van dien tijd. 
iemand van zijn zwak en grillig karakter, hoezeer aanvankelijk niet bestand tegen de inblazingen zijner zooveel op hem vermogende gemalin, om zijn wettigen erfgenaam te verstooten, gepijnigd door te laat naberouw over dien stap, aan het malen raakte. Dit zij hoe het zij, de buitensporigheden van den Sultan namen zoo toe, dat niemand aan het Bantamsche Hof zijn leven zeker was en de Koningin met Pangéran Sjarief en de voornaamste rijksgrooten te Batavia haar toevlucht zocht. Om groote beroering te voorkomen, moest de Indische Regeering nu wel tot krachtige maatregelen overgaan. De Commondeur te Bantam, George Tammo Falck, nam op haar last den Sultan gevangen, die eerst naar het eiland Edam en daarna naar Ambon werd opgezonden. Tevens nam de Compaguie bij plechtige akte van 28 November 1748 het geheele Bantam che rijk tot den dood of het herstel des Sultans onder haar beheer, waar voortaan Ratoe Sjariefa uit haar naam als Regentes het bewind zou voeren 1.

Schijnbaar waren door deze staatswisseling de rust en vrede in Bantam geheel hersteld, en nog op den laatsten dag des jaars 1749 kon de Gouverneur-Generaal van Imhoff met bijzondere bevrediging aan Bewindhebbers melden, dat dit rijk sedert jaren niet zulk eene hoeveelheid peper geleverd had. Ratoe Sjaricfa was toch scherpzinnig genoeg, om in te zien, dat haar macht uitsluitend op den steun der Indische Regeering berustte; met de uiterste zorg behartigde zij derhalve de belangen der aan de Compagnie zoo dierbare peperteelt. Daarentegen achtte zij zich verre verheven boven de inlandsche bevolking, die zij met den grootsten overmoed behandelde en door buitensporige gierigheid geheel van zich vervreemdde; ja zij ontzag zich zelfs niet, in strijd met het bij alle oostersche hoven bestaande gebruik, de bijwijuen haars gemaals uit den Dalem te zetten en de aanzienlijken op schamperen toon voor lafaards uittemaken, omdat zij zo: der spoor van verzet hun wettigen vorst uit hun ridden hadden laten oplichten. Eindelijk liep de tot den rand gevulde beker over, en ontstond er onder de Bantamsche landbevolking een algemeen verzet tegen de gehate vreende indringster. Kort voor van Imhoff's overlijden werd in het latst van October 1750 de vaan des opstands ontrold door den priester Ki Tapa,

1 Deze akte is afgedrukt bij de Jonge, D. X, bl. 148-152, welk werk op bl. 137-140 de officiëele berichten over de krankzinnigheid en wegvoering van Sultan Zeinoe'l Arifien mededeelt.

Downloaded from Brill.com04/26/2023 04:53:37AM 
een kluizenaar, die in de weinig toegankelijke holen van den berg Moenara door het landvolk als heilige vereerd werd ${ }^{1}$. Op dezen berg, die zich in het toen nog tot Bantam behoorende westerdeel van Buitenzorg tot nabij de grensrivier Tjidani uitstrekte, verzamelde hij al de ontevredenen om zich: onder anderen Ratoe Siti, een der zoo smadelijk van het hof verjaagde vrouwen des verbannen Sultans, en Ratoe Bagoes Boeang, ouechten zoon van den kort te voren te Batavia overleden Panembahan Pangéran Poetra, die blijkens de Memorie van Gollenesse reeds in het begin der regeering van Sultan Zeinoe'l Arifien derwaarts was uitgeweken.

Daar de berg Moenara slechts tien uur van 's Compagnies post Tangeran verwijderd was, zond de Indische Regeering, zoodra zij van deze gebeurtenissen kennis droeg, eenige troepen derwaarts, waarop de opstandelingen westwaarts trokken en een kleine door de Koningin tegen hen uitgezonden krijgsmacht versloegen. Onbegrijpelijk snel verspreidde de opstand zich nu door geheel Bantam, waartoe veel bijdroeg het gerucht, dat de bij de bovenlanders zoo beminde Panembahan niet gestorven was, maar an het hoofd van het verzet stond. Weldra verscheen $\mathrm{Ki}$ Tapa met een groote macht in de onmiddellijke nabijheid der hoofdstad eil versloeg daar den 9den November het legertje der Koningin, versterkt door een gering aantal militairen der Compagnie, zoodat de bevelvoerende officier Philippe en twaalf soldaten het leven lieten en de beide medegenomen veldstukjes veroverd werden. Algemeen werd nu de afval

$1 \mathrm{Ki}$ of $\mathrm{Kiai}$ is bij de Javanen een zeer gebruikelijke eeretitel voor per-

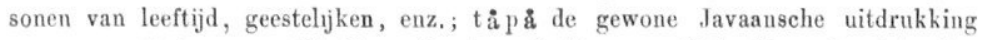
voor een kluizenaar. $\mathrm{Ki}$ Tapa is dus slechts een titel, dien wij echter behouden moeten, omdat de naam en afkomst van dit energieke hoofd des opstands ons niet bekend zijn. In den Atlas van Melvill zoekt men den Moenara te vergeefs; het is een der toppen van den Goenong Mentjerreh, want de ligging tegenover Koeripan blijkt uit Radermachers reis door Jakatra (Tijdschr. Ned. Indie, 1856, D. II, bl. 175). Volgens Prof. Veth (Java, D. III, bl. 97) is daar nog heden een heilige grot, waarschijulijk dezelfde, die aan Ki Tapa ten verblijf strekte. Niet zonder reden koos deze zijn toevlucht in dit oord, vol sporen van den ouden Hindoe-godsdienst, waartoe ook het bedrijf der op Java zoo dikwijls voorkomende tapa's behoort. In hetzelfde jaar 1750 bracht een andere Ki Tapa geheel Oost-Madoera in rep en roer, en in 1756 schreef de kundige Hartingh als Gonverneur van Java's Noordoostkust van de tapa's: *dat dit "gespuis Java van ouds eygen is, insonderheit bij troubele tyden en telkens "diversie baart in onse desseynen;" (verg. de Jonge, D. X, bl. LXVII, 177 en 312). 
in de omgeving van Ratoe Sjariefa; niet alleen voegden zich vele aanzienlijken en ambtenaren bij de rebelien, maar ook een broeder van den Sultan, Radeen Derma, en dien broeders zoon, Pangéran Madoera. Wel had de Indische Regeering terstond na de eerste nederlaag aanzienlijke versterking naar Bantam gezonden, maar toen hare krijgsmacht, groot 460 koppen, op 21 November tegen het meer dan 7000 man bedragende leger der opstandelingen uittrok, moest deze na een hevig gevecht met verlies van 6 gesneuvelde officieren en 27 mindere militairen en met opoffering van 3 stukken en veel ammunitie opnieuw afdeinzen. Binnen Bantam werd thans de toestand inderdaad hachelijk, en het scheen zelfs twijfelachtig, of de daar $\log$ a anwezige troepen, ter sterkte van 278 Europeanen en 153 inlandsche soldaten, voldoende waren tot hehoorlijke verdediging der drie versterkingen, die de Compagnie in de hoofdstad bezette, waarvan het fort Diamant den Dalem omsloot, terwijl Speelwijk den hoofdmond der rivier en de post Karang Hantoe de oostelijke monding verdedigde. Hoewel het gelukte, den vijand te verdrijven uit een steenen gebouw, dat den Dalem bestreek, waren de rebellen door de behaalde voordeelen zoo overmoedig geworden, dat zij een poging waagden, om de laatstgenoemde sterkte te overrompelen. Gelukkig had de Commandeur, door zijne verspieders van dit plan onderricht, de bezetting van den post versterkt en de nadering door friesche ruiters en gebroken glas bemoeielijkt. Toen dan ook de vijand op een donkeren nacht de wallen wilde beklimmen, werd hij door den bevelhebber te Karang IIantoe, luitenant Wassenberg, zoo warm ontvangen, dit hij met groot verlies teruggeslagen werd.

Op het eerste bericht der nederlaag van 21 November zond de Indische Regeering niet alleen onmiddellijk een compagnie infanterie en 250 matrozen tot versterking van het zwakke Bantamsche garnizoen, terwijl zij voor alle eventualiteiten 70 man naar Tangeran afzond, maar zij begreep ook, dat men ernstig moest overwegen, welke politieke maatregelen genomen konden worden, om de rust te herstellen. De pas opgetreden, met de zaken van Bantam zoo vertrouwde Gouverneur-Generaal Mossel kon zich niet ontveinzen, dat de door hem in $\mathbf{1 7 4 7}$ tot stand gebrachte regeling der troonsopvolging niet gehandhaafd kon worden. Duidelijk bleek het, dat de ontevredenheid der inlandsche bevolking over de vervanging der oude dynastie 
door een geheel vreemd geslacht aan den opstand de groote kracht schonk. Bovendien had Ratoe Sjariefa door hare toomelooze heerschzucht elk recht op de regeering verbeurd, terwijl Pangéran Sjarief, die zich steeds in zijn serail ophield, geheel ongescl.ikt was, om krachtig als vorst op te treden. Hoezeer ten volle overtuigd, dat beide ten spoedigste uit Bantam moesten verwijderd worden, ging de Indische Regeering aarzelend tot dien gewichtigen stap over. Wel was zij daartoe gerechtigd, nadat zij in 1748 bij de bovengenoemde acte het Bantamsche rijk ouder haar beheer had genomen, terwijl Ratoe Sjariefa slechts als Regentes namens de Compagnie het bewind voerde en in belangrijke zaken niet zonder voorkennis van den haar toegevoegden regecringsraad van den Kroonprins en eenige rijksgrooten mocht handelen; maar om den schijn te vermijden, als had men den Sultan alleen nit eigenbaat onttroond, was het bedoelde staatsstuk nooit publiek gemaakt, en had men het ong'uikend toegelaten, dat Ratoe Sjariefa in het openbaar als soevereine vorstin optrad. In weerwil dezer bezwaren waren beslissende maatregelen dringend noodzakelijk. Dientengevolge werd na rijpe overweging bij Resolutie van 23 November 1750 de Bantamsche Commandeur gelast, de Koningin en den Kroonprins goed- of kwaadschiks naar het eiland Edam te vervoeren, waar zij met de an hun rang verschuldigde eerbewijzingen zouden verblijven, totdat er nader over hun toekomstig lot beschikt werd. Voorts werd het opzicht over den Dalem toevertrouwd aan Pangéran Aria Adi Santika, den cudste der nog in de hoofdstad anwezige broeders des Sultans. Gelukte het dezen prins na de afzetting der zoo algemeen gehate Ratoe Sjariefa de bevolking tot zich te trekken, dan zou hij tot PrinsRegent verheven worden. Daar het echter der Compagnie op zich zelf vrị onverschillig was, wie den Bantamschen rijkszetel hekleedde, als er maar goed voor de peper gezorgd werd, was het geenszins haar belang, tegen de meerderheid der inlandsche bevolking de keuze van den toekonstigen vorst met geweld door te zetten. De Commandeur werd dus tevens gemachtigd, met den hoofdrebel Ratoe Bagoes Boeang in onderhandeling aan te treden, zoo deze daartoe de eerste stappen deed '.

1 Het moet hier opgemerkt worden, dat de aard van dezen in de gevolgen zoo gewichtigen opstand door vele schrijvers over de geschiedenis van den Archipel geheel verkeerd wordt voorgesteld. De dikwijls goed onderrichte gezantschapsecretaris Elie du Bois nam in zijne Vies des Gouverneurs-généraux (Hist. 
Falck volbracht den hem gegeven last met beleid; slechts het laatste gedeclte daarvan kon niet uitgevoerd worden, daar de rebellen geene toenadering tot de Compagnie wilden. Weldra bleek het zelfs, dat zij verbindingen hadden aangeknoopt met de Engelschen in Benkoelen en de hoop koesterden, met hunne hulp de Hollanders voor goed uit Bantam te verdrijven. In den aanving van 1751 kon die hoop zoo ongegrond niet schijnen. Hoewel toch de Indische Regeering het Bantamsche garnizoen tot 1000 Europeanen en 350 iulanders versterkt had en het bevel daarover toevertrouwd had aan den luitenant-kolonel Ferdiuand Anton Graaf van Ranzow, door cen vorig verblijf te Bantam met de zaken aldair goed bekend, kon de door ziekte geteisterde bezetting zich nict buiten de hoofdstad wagen, om

générale des voyages, T. XVII, la Haye 1763, p. 255-257) ter kwader ure eenige brieven over uit den Europeeschen Mercurius van 1752, D. II, St. 2, waarin de opstand wordt toegeschreven aan de over Ratoe Sjariefa's afzetting ontevreden aanhangers dezer vorstin. Dit onjuist bericht is overgenomen door v a $n$ K ampen (Nederlanders buiten Europa, D. III, bl. 80-82), hoewel deze schrijver voor dit deel van zijn werk veel officiëele stukken raadpleegde, door den onkritischen Lauts (Nederlanders in Indië. D. III, bl. 87) en laatstelijk nog door Prof. de Hollander (Land-en Volkenkunde van Ned. O. Indie, eerste druk, D. I, bl. 33) en door Prof. Meinsma (Geschied.der Ned. Oost-Indische bezitt., D. I, bl. 152). De ware oorzaken van den opstand kenden reeds de met de Bantamsche papieren vertrouwde van Breugel (ter boven aangehaalde plaats, bl. 112 en 316), Hageman (Java, D. I, bl. 214) en op hun voetspoor Prof. Veth (Java D. II, bl. 495-497), hoewel laatstgenoemde, evenals Hageman, de opstandelingen later weder tot de partij der koningin rekent.

Al dezen schrijvers was het ontgaan, dat aan de Hollandsche vertaling van $\mathrm{du}$ Bois (Hist. Beschrijuing der Reizen, D. XX, Amst. 1765, bl. 389-397) is toegevoegd een Nader Bericht over den Bantamschen oorlog, hetgeen niet alleen over de krankzinnigheid des Sultans, de willekeurige maatregelen van Ratoe Sjariefa en over het ontstaan van den opstand goed was ingelicht, maar zelfs nu nog naast de officiëele bescheiden met vrucht kan worden geraadpleegd. De Jonge, de eenige onzer geschiedschrijvers, die van dit verhaal kennis nam, geeft in het laatste deel van zijn groot werk (D. X, bl. 166-176) de voor het begin van den opstand zoo merkwaardige Secrete Resolutiën der Indische Regeering van November 1750; het verdere verloop van den opstand behandelt hij echter korter en bepaalt zich hoofdzakelijk tot de beknopte mededeelingeu der Algemeene Brieven aan Bewindhebbers. Daar Prof. Veth terecht klaagt, dat de berichten over deze gebeurtenissen in Bantam verward en onderling in strijd zijn, en daar de wisselvallige loop van dien oorlog inderdaad opzettelijker behandeling verdient, dan daaraan tot dusver te beurt viel, scheen het mij geen overbodige arbeid, daarvoor op het Rijksarchief de Secrete Resolutiën en de geheime Indische Briefboeken over de jareu 1751 en 1752 te raadplegen. Daaraan is meerendeels ontleend, wat hier verder over dezen laatsten oorlog der Compagnie met Bantam wordt medegedeeld, waar voorzoovernoudig naar de gebruikte ofticiëele stukken verwezen wordt. 
de in de onmiddellijke nabijheid verschanste opstandelingen aan te tasten. Te Markasana 1 hadden deze met behulp van Hollandsche overloopers een uitgestrekt versterkt legerkamp opgericht, dat door verschillende met geschut bewapende bentings verdedigd werd en Bantam van de landzijde geheel insloot. Bedenkt men, dat deze stad in 174.7 volgens Mossel 10,000 inwoners telde (de Jonge, D. X, bl. 118) en dat, hoevele dier ingezetenen zich ook bij de rebellen mogen gevoegd hebben, het meerendeel toch wel in hunne oude woonplaats zal gebleven ziju, dan begrijpt men, hoeveel zorg er vereischt werd, om te voorkomen, dat de toevoer van levensmiddelen voor de bevolking en het talrijke garnizoen ook te water werd afgesneden. De Baai van Bantam werd daarom voortdurend door gewapende sloepeu der Compagnie open gehouden, en toen de vijand in Februari $175 \mathrm{l}$ een dier pantjallangs op een donkeren nacht overviel en al de opvarenden afinakte, werd deze zeemacht door een fregat en bark uit Batavia versterkt.

Bij den zegevierenden loop van den opstand kon zelfs niet belet worden, dat die oversloeg naar de sinds lang tot het rịjk van Bantam behoorende Lampongsche Districten, aim wier behoud der Compagnie te meer gelegen was, dewijl zij het meeste der te Bantam geleverde peper voortbrachten, en omdat de Engelschen, die bij den vrede tusschen Groot-Brittanje en Nederland bezwaarlijk den opstand openlijk over zee konden steunen, dien van Benkoelen uit in Zuid-Sumatra op allerlei bedekte wijzen zouden schragen, om het uitsluitend bezit der peper voor zich te verkrijgen. De Indische Regeering was echter, evenals in den geheelen loop der achttiende eeuw, zoo schraal uit het moederland van de noodige manschappen voorzien, dat zij, die terzelfder tijd haar vissal, den jeugdigen Soesoehoenan Pakoeboewana III, tegen zijn oom Mangkoeboemi met hare troepenmacht moest beschermen en reeds zooveel soldaten naar Bantam had moeten zenden, niet bij tijds kon zorgen voor den kleinen post, dien zij sedert 1737 aan de bovenrivier Toelang Bawang te Boemi Agong bezet had. Toen dan ook de slechts door paalwerk omringde sterkte Valkenoog door de Bantamsche rebeilen en vele Lampongers onder aanvoering van den peranakan-Chinees Sibali was ingesloten, werd de zwakke bezetting weldra zoo afgemat door gedurige nachtelijke anvallen, dat de

1 Misschien dezelfde plaats, die op de kaart van Melvill Kartasana heet. Downloaded from Brill.com@4/26/2023 04:53:37AM 
vaandrig Hendrik Groenendıjk met de zijuen heimelijk den post verliet en in een onzeewaardig schuitje de rivier afzakte. Aan den mond stuitte men op een Bantamsch vairtuig, dat geënterd werd, zoodat de bezetting wel met verlies van haar bevelhebber, die bịj deze gelegenheid den heldendood stierf, behouden Bantam bereikte, maar het gezag der Compagnie voorshands in de Lampongs vernietigd was.

Waar alles zoo voor den wind ging, konden de hoofdopstandelingen zonder schroom hunne ware bedoelingen doen blijken. Openlịk verkondigden zij, dat zij de Nederlanders niet langer als slaven wilden dienen. Ratoe Bagoes Boeang liet zich zelfs tot Sultan uitroepen en nam als zoodanig den titel Aboe'n Natsr Mohammed Joesoef Achmat Adil Arraliek Fiddien aan, terwijl hij, om aan zijne verheffing een schijn van legitimiteit te verleenen, met Ratoe Siti in den echt trad, onbekommerd, dat haar wettige gemaal, de naar Ambon verbannen Sultan, nog in leven was. $1 \mathrm{Ki}$ Tapa, die terecht of teonrecht zich voor een afstammeling der oude vorsten van Jakatra uitgaf; beweerde zelfs, dat hij de Compagnie uit zijn erfland zou verdrijven. Was het duidelijk, dat het Nederlandsch gezag ouder deze omstandigheden niet met de rebeilen kon onderhandelen, en dit evenmin raadzaam, daar Ratoe Bagoes Boeang, bij een gehuwde vrouw in overspel verwekt en door zijn vader den

1 Daar bij onze moderne opvoeding de bijbelsche geschiedenis zeer in het vergeetboek raakt, mag hier wel herinnerd worden aan den listigen raad van Achitophel, den Fouché onder de staatslieden vau het oude rijk van Israël, toen Absalom zijn vader David wilde onttronen en dien grijzen vorst uit Jeruzalem verdreven had. In den naieven stijl onzer Staten-vertaling luidt die raad aldus (2 Sau.uel XVI, 21-23): "Achitophel zeide tot Absalom: " "Ga in tot de bijwijven uws " nvaders, die hij gelaten heeft, om het huis te bewaren; zoo zal gansch Israël " "hooren, dat gij bij uwen vader stinkende zijt geworden, en de handen van " "allen, die met " zijn, zullen gesterkt worden." "Zoo spanden zij Absalom reene tent op het dak, en Absalom ging in tot de bijwijven zijus vaders voor "de oogen van het gausche Israël. En in die dagen was Achitophels raad, dien hij "raadde, alsof men naar Gods woord gevraagd had; alzoo was alle raad "van Achitophel, zoo bij David als bij Absalom." Treffend bewijs voorwaar der stabiliteit van oostersche zeden en gewoonten gedurende een tijdsverloop van acht en twintig eeuwen, maar niet minder merkwaardige overeenkomst, als men let op het versehil in hemelstreek tusschen Palestina en Java en op den onderscheidenen aard der bewoners van beide landen. In de geschiedenis van Bantams koningen, die uit Arabië afkomstig, in strijd met het gebruik aan het hof van Mataram, steeds zuiver Arabische namen dragen, staat men echter veelal meer op Semietischen dan op Indischen of Polynesischen bodem. 
Panembahan nimmer als zoon erkend, op den Bantamschen troon geen de minste aanspraak had, ook aan Pangéran Santika was het tot dusver niet gelukt, onder de bevolking eenigen noemenswaardigen aanhang te verkrijgen, waarschijnlijk omdat deze gebrekkige, bejaarde en hoogst zuinige prins voor de vortelijke waardigheid minder geschikt was. Falck en de hem omringende raad der voornaamste ambtenaren in Bantam meenden echter, dat de uit hun aard achterdochtige inlanders huiverig waren, zich openlijk voor den Pangéran te verklaren, nit vrees dat het der Compagnie met zijne verheffing geen ernst was, en dat er spoedig weer nieuwe veranderingen op til zouden zijn; zij stelden dus voor, den Prins ten spoedigste tot Sultan te verheffen. Zoover wilde de Indische Regeering echter nog niet gaan; daar de op Ambon verblijvende Sultan nimmer officiëel was afgezet, kon er volgens hare meening bij zijn leven slechts eeñ Pangéran Ratoe of Regent benoemd worden. Zelfs achtte Mossel het wenschelijk, den naar Ceilon verbanuen wettigen Kroonprins Pangéran Arief met diens oom Paugéran Bantam, voor wier verwijdering thans geen reden meer bestond, terug te roepen, om zich zoo noodig van hem te bedienen.

Dit werd bij geheime Resolutie van 18 Januari 1751 besloten en Falck tevens gelast, in Buntım een rijkst:tad der prinsen v:n den bloede en rijksgrooten te beleggen, waar hij de afzetting van Ratoe Sjariefa en van den door haar opgedrongen Kroonprins en de verkiezing van Santika tot Prins-Regent zou voorstellen. Tevens werd overwogen, hoe te handelen met de ontzette Koningin en haar neef. Mossel meende, dat Ratoe Sjariefa, aan wie de Compagnie zooveel verschuldigd was - had hij wellicht ook vroeger te diep in hare donkere oogen gestaard -- daar zij nu van alle macht beroofd was, zonder gevaar te Batavin kon blijven. Behalve Johan Gideon Loten, die, eerst onlangs als Gouverneur uit Makassar teruggekeerd, zitting in den Raad van Indië genomen had, vonden al de overige leden van dit hooge stuatslichaam zulks ten hoogste bedenkelijk, daar men met geen mogelijkheid beletten kon, dat deze in listige knepen zoo doortrapte feeks van uit Batavia in het naburige Bantam opnieuw allerlei onheilen aanrichtte. Bij meerderheid van stemmen werd zij derhalve naar Saparoea, de Kroonprins naar Banda verbannen. De trotsche, cerzuchtige vrouw zou echter ha r val eit vernedering
Downloaded from Brill.come4/26/2023 04:53:37AM 
niet lang overleven; weldra werd zij door een zware ziekte aangetast, die eerst haar vervoer belette, en waaraan zij reeds den $10^{\text {den }}$ Maart bezweek. De van den aanvang af hoogst onbeduidende Pangéran Sjarief bereikte daarentegen een jaar later het oord zijner bestemming, waar hij meer dan dertig jaar het brood der ballingschap in vrede en rust genoot. ${ }^{1}$

Voorshauds konden al deze maatregelen weinig uitwerken, zoolang de Compagnie en haar beschermeling, de nieuwe Regent, alleen in de hoofdstad geboden en daar door de rebellen bleven ingesloten. Voor het einde van den regentijd in Mei viel er aan geen operaties in het open veld te denken, en ook toen moest wegens den verzwakten toestand van het Indische leger de komst der uit Europa reikhalzend verbeide troepen worden afgewacht. Zelfs toen de macht der opstandelingen zich verdeelde, en $\mathrm{Ki}$ Tapa in Juni met een deel van hun leger naar de Tjidani optrok, om ter uitvoering zijner bedreiging de Compagnie op haar eigen erf te bestoken, achtte Falck zich buiten staat, de te Batavia zoo gewenschte afleiding uit Bantam te beproeven en den Rebellen-Sultan in het kamp van Markasana aan te tasten. Wegens de vele zieken onder Bantams bezetting kon hij ter nauwernood 700 man onder de wapens brengen, terwijl Ratoe Bagoes, door op de gong te slaan, in weinig tijds beschikken kon over 10,000 krijgers, waarouder vele door de dweepzieke leeringen van $\mathrm{Ki}$ Tapa tot de grootste doodsverachting waren opgehitst. 2 Deze priester, aan wien men noch politieke bekwaambeden noch krijgsbeleid ontzeggen kan, viel inmiddels met zoo veel kracht in de Jakatrasche Benedenlanden, dat men een oogenblik voor het behoud van het van troepen ontbloote Batavia bezorgd kon zijn, waarom wij omtrent het verloop van dezen wel beraamden aanval eenige meerdere bijzonderheden moeten mededeelen.

Nadat de Indische Regeering reeds in Mei vernomen had, dat Ki Tapa met kracht van volk den weg van Bantam naar Djasinga voor geschut liet in orde brengen, berichtte de kapitein-luitenant Johannes Vertholen, bevelhebber der veldschans Tangeran, dat dit hoofd des opstands in den nacht van 12 op 13 Juni met 800 man, 30 paardeu en 6 draaibassen den berg Moenara

1 Zie de Secrete Resolutiën van 18 Januari en 2 April 1751 en van Breugel, t. a. pl., bl. 316. Voor het vermoeden in de Hist. Beschr. der reizen, dat Ratoe Sjariefa haar einde door vergif verbaastte, vond ik in de officiëele stukken geen spoor.

${ }^{2}$ Zie Faleks brief an de Indiscbe Regeering van 15 Juni 1751. 
opnieuw bezet had, terwijl de opstandelingen de nabij de Tjidani gelegen dorpen Kalipaten, Kadimongan, Djampang en Koeripan in den brand staken. Daar het nu duidelijk bleek, dat de Indische Regeering op de verdediging van haar eigen grondgebied bedacht moest zijn, zond zij, die reeds de compagnie infanterie van den luitenant-kolonel van de Poll te Meester-Cornelis geplaatst had, met den meesten spoed een afdeeling vall 200 infanteristen, 150 dragonders en 300 inlanders naar de bovenrivier Tjidani. Hierover werd het bevel toevertrouwd aan den majoor van de dragonders der lịfwacht, den luitenant-kolonel Willem Hendrik van Ossenberch, die in den vorigen herfst grooten moed betoond had bij het verdrijven der benden van Mangkoeboemi uit de Bageleen en reeds in December, toen de Bantamsche opstand hoe langer hoe meer een dreigend aanzien verkreeg, met zijn dragonders uit Java naar Batavia was opgeroepen. Deze kleine krijgsmacht ondervond aanvankelijk vertraging in haar opmarsch, daar de manschappen en paarden niet van voldoenden leeftocht voorzien waren. Nauwelijks had z.ij hare bestemming bereikt, of zij werd den 20 sten Juni dour den vijand overvallen, die met 6000 man op den berg Moemara en in de aau den voet gelegen negorij Katimagonan gekampeerd was en geheel onverwacht beneden Djampang de rivier overtrok. Van Ossenberch, die met zijne cavalerie in de holle modderwegen niets kon witrichten, moest, toen hị wa een hardnekkig gevecht van anderhalf uur al zijne ammunitie verschoten had, met verlies van 16 dragonders, waaronder de luitenant Christian Schulenburg, voor de overmacht wijken en trok op Buitenzorg terug. Onmiddellịk zond de Indische Regeering hem de noodige ammuuitie, maar tevens, om hare troepenmacht meer te concentreeren, den last naar Drechterland (Serinsing) terug te trekken, waar van de Poli zich uit Meester-Cornelis met hem zou vereenigen. Ook werd voor de bezeiting der forten aan de rivier Angkee, aan de Kwal of mond der Tjidani, te Tangeran en te Westergo of Tjampea de noodige zorg gedragen, terwijl de verste post der Compagnie in de Bovenlanden, het aan de Tjikaniki, den linker zijtak der Tjidani, gelegen Penjaboengan reeds op last van van Ossenberch was ontruimd. 1

Tntusschen aarzelde $\mathrm{Ki}$ Tapa niet, van zijne overwinning de meeste viuchten te trekken. In het begin van Juli trok

1 Zie brief van v. Ossenberch dd. 30 Juui en de Secrete Resolntiën van 21,22 en 24 Juni 1751. 
hij met groote macht te Salabantar de Tjidani over en marcheerde van daar naar het over de Angkee gelegen Poudok Boental en verder langs dien stroom naar Tjilidoek, terwijl zijne troepen de tusschen beide rivieren gelegen suikermolens en de weinige jaren te voren aan Nederlandsche boeren uitgemeten erven te vuur en te zwaard verwoestten, waardoor de eenige krachtige poging der Compagnie tot Europeesche kolonisatie op Java in de geboorte gesmoord werd. ${ }^{1}$ De toestand werd nu inderdaad hachelijk, vooral daar de door Vertholen uit Tangeran tot bescherming der boeren afgezonden kapiteinluitenant der infanterie Voltz aanvankelijk wegens onwil zijner inlandsche soldaten naar het fort moest terugkeeren. De Indische Regeering liet echter den moed niet zakiken. Het hoofd van 's Compagnies militie in Indië, de brigadier Jan Cornelis Convert, moest volgens Resolutie van 4. Juli met al de nog te Batavia beschikbare troepen, de marine der werf en 360 matrozen te Tanah Abang een legerkamp betrekken, waar van Ossenberch zich uit Tanjong bij hem vervoegen zou. Het betrekken der wachten in de stad en de bezetting van het kasteel en de wallen werd inmiddels aan de compagnieën der burgerschutterij en der gewapende pennisten toevertrouwd.

De nood was hoog gerezen; sedert ruim een eeuw had de boofdstad van Neerlandsch-Indië geen inlandschen vijand dus in nare onmiddellijke nabijheid gezien. Nu echter keerde de krijgskaus ten gunste der Compagnie, vooral daar de lang uit het moederland verwachte schepen met recruten thans achtereenvolgens binnenvielen. Nog voor de aạkomst dezer versterking had de onvermoeide Voltz de orde onder zijne troepen hersteld en was met zijne zwakke compagnie en een driehonderdtal inlanders naar Tjilidoek gemarcheerd, waar Ki Tapa meer dan 2000 man onder zijne bevelen telde. Onderweg tusschen de suikermolens van Babakan en Tjikokol werd hij den $6^{\text {den }}$ Juli door de rebellen angetast, die na een hevig gevecht met 40 dooden en 80 gekwetsten moesten afdeinzen; ook van onze zijde leed men groot verlies, vooral door het sneuvelen van den trouwen Tangeranschen Regent Aria Soeta

1 Zie over deze kolonisatie van 1743 de studie van Jhr. J. K. J. de Jonge achter het verslag der Staatscommissie van 16 Juni 1857; ook het journaal van den Gonv. Gen. van Imhoff over diens reis naar de Jakatrasche Bovenlanden in 1744 (B̈̈jdr. Inst., R. 2, D. VII, bl. 229) en de opstellen der heeren Hageman en Schiff in Tijdschr. Bat. Gen., D. XVII. 
di Taga en van den luitenant der Boetonders, hetgeen onder de inlandsche troepen zoo groote verslagenheid verwekte, dat Voltz van elke poging tot vervolging van den vijand moest afzien. Ten spoedigste zond nu de Indische Regeering een deel der versch aangekomen soldaten, zoowel naar Tangeran als naar de beide colonnes van Convert en van Ossenberch, die tusschen Batavia en de Angkee ageerden. Daardoor werd Ki Tapa reeds den 13den Juli te Tjilidoek van twee zijden door Voltz en van Ossenberch op zoo krachtige wijze aangetast, dat men eene beslissende overwinning behaalde, waarbij de laatstgenoemde aan de onversaagdheid der dragonders en der infanterie van Voltz hoogen lof toezwaaide. Bij deze gelegesheid verloor Ki Tapa 2 veldstukken, 3 draibassen en ruim 150 docden, "meest amokspuwers"; hij vluchtte met zoo groote overhaasting naar de Tjidani, dat van Ossenberch de hoop koesterde, dat hij het gebied der Compagnie geheel ontruimen en zich op den Moenara terugtrekken zou. De Raad van Indië, die in deze benarde dagen met evenveel voortvarendheid als staatsmansbeleid te werk. ging, nam op den d:ig zelf dier overwinning, het kloek besluit: 680 Europeanen en 900 inlanders onder Convert, van Ossenberch en van de Poll over zee naar Bantam te zenden, om die stad te ontzetten, terwijl de reeds van daar opgeroepen van Ranzow met Voltz, een duizendtal Europeanen en 1200 inlanders de grenzen van Jakatra tegen Ki Tapa zoude bewaken. Hoe verstandig dit besluit was, bleek weldra uit een brief van Falck, die door spionnen uit het kamp te Markasana vernomen had, dat Ki Tapa terstond na zijne nederlaag bij den Rebellen-Sultan op de spoedige toezending van 1000 man met geschut had aangedrongen. 1

Binnen het zoo lang ingesloten Bantam was nu weldra een aanzienlijke troepenmacht bijeen, vooral daar een aantal der net de Patriasche schepen overgekomen soldaten, zonder te Batavia te landen, rechtstreeks naar Bantam gezonden waren. Daar Falck door zijne verspieders nauwkeurig onderricht was van den staat der door de rebellen om en bij Markasana opgerichtte bentings en verdedigingsliniën, kon Convert reeds op 23 Juli den aanval op het door de vele troepenzendingen aan Ki Tapa verzwakte leger van Ratoe Bagoes ondernemen. In weerwil van eeve hardnekkige verdediging vermeesterde hij

1 Secrete Resolutiën van 4 en 13 Juli; Brieven van Vertholen dd. 4, 7 en 9 Juli, van v. Ossenberch dd. 13 en 14 Juli, van Falck dd. 15 Juli 1751. 
eer'st eene benting en dan achrereenvolgens de zeven overige versterkingen der opstandelingen, die ijlings naar het gebergte terugweken. In het daarop door zijne troepen bezette kamp vond men een dertigtal stukken geschut, waaronder de in November te Grobejak 1 verloren kanonnen; voorts wat niet minder merkwaardig was, een brief van den Engelschen bevelhebber te Benkoelen, waaruit ten duidelijkste bleek, hoezeer deze onze Europeecche mededingers het slagen van den opstand genegen waren. Buitengemeen groot waren de gevolgen dezer schitterende overwinning. Uit eigen beweging omlerwierp zich de bevolking der oostelijke kustdistricten Pontang en Tauara, terwijl Voltz van Tangeran uit op den zelfden 23sten Juli de Chineezen der door de Bantamsche Sultans verpachte suikerplantage te Kramat ontzet had. Zelfs in de hergstreken begon men in onderwerping te komen; van daar werd de blijkbaar als een vorstelijk poesaka beschouwde olifant van den Rebellen-Sultan naar Bantam gebracht en op bevel der Hooge Regeering aan den Prins-Regent uitgeleverd. Ter aanmoedicing werd de op het hoofd van den kruitmaker dier opstandelingen gestelde prijs van 500 rijksdaalders terstond uitbetald, zoodra deze door de inlanders was uitgeleverd. Ook zond Convert reeds den 26sten Juli op uitdrukkelijken last der Indische Regeering van Ossenberch met de noodige troepen over zee naar Tjiringin, welks bewoners voornamelijk den opstand na:r de Lampongs overgebracht en deswegens eene afzonderlijke tuchtiging verdiend hadden. Door tegenwind in Straat Sunda kwam van Ossenberch eerst in het begin van Augustus voor Tjiringin; onderwijl had de Pangéran van dit district zich geheel vrijwillig over land naar Bantam begeven, om daar het oppergezag der Compagnie te erkennen. Daar de bevolking van Tjiringin zich eveneens terstond aan van Ossenberch onderwierp, kon de voor deze plaats bestemde straf worden kwijtgescholden en laatstgenoemd legerhoofd de terugreis naar Bantam aanvaarden. 2

Welk een gunstigen keer de stand van zaken te Bantam in een groote week door deze gebeurtenissen verkregen had, weldra bleek het, dat de bevrediging vin het geheele rijk meer tijd

1 Deze herhaaldelijk in de stukken van dien tijd vermelde plaats is ongetwijfeld de aan de oostelijke nitloopers van het Anjersche Gebergte liggende dessa Krapiak.

2 Brieven van Convert aan de Iud. Regeering dd, 23, 26 en $29 \mathrm{Juli}$, 2, 4 en 5 Aug.; Secr. Resol. van 25.Julibowh 2 daded from Brill.com04/26/2023 04:53:37AM 4e Volgr. V. 
zou kosten, en dat de hoofden der opstandelingen rog geenszins gezind waren den strijd op te geven. Ook bemerkte Convert spoedig, dat hij van den tragen, ziekelijken, bij de bevolking weinig geachten Prins-Regent slechts geringe hulp te wachten had; toch was die nagenoeg onmisbaar, daar er alleen tot het slechten der versterkingen en aardewerken in het kamp van Markasana wel een duizendtal arbeiders noodig waren. Gelukkig vond hij thans krachtigeu steun bij den Pangéran Moestafa Djaja Mangala, zoon van een eigen broeder des naar Ambon verbannen Suitans en van moederszijde kleinzoon van den hierboven genoemden Panembahan, waardoor hij op grooten aanhang bij de bovenlanders kon rekenen. Toen Convert nog in de eerste dagen van Augustus met zekerheid vernumen had, dat de rebellen met groote macht Lautjar en andere bergdorpen aan den voet van den Karang hadden bezet en een voorhoede van 1000 man onder Pangéran Madoera naar Tjibodas vooruitschoven, hoogst waarschijnlijk om van daar Serang aan te tasten, vroeg hij van de Indische Regeering verlof, hen onder leiding van Moestafa am te vallen. Bij Resolutie van $12 \mathrm{Au}$ gustus werd dit rerzoek toegestaan, mits hij te Bantam de noodige macht achterliet, oin deze plaats, Pontang en Tanara te dekken; echter verbond de Raad van Indië, gedachtig aan den beproefden stelregel der Compagnie, dat men slechts in de alleruiterste noodzakelijkheid in het binnenland moest oorlog voeren, en dat elke krijgsbeweging een beperkt doel moest hebben, aan die machtiging het uitdrukkelijk beding, dat Convert in geen geval verder dan Lantjar mocht gaan.

Dientengevolge aanvaardde Convert met een deel zijner troepen en de Bantamsche hulpbenden onder Moestafa den tocht naar het destijds weinig door Europeanen bezochte gebergte van Pandeglang, bij welke gelegenheid zijn kloeke onderbevelhebber geen minder lauweren behaalde, dan hij in de vorige maand zoo in het Tangeransche als in de onmiddellijke nabijheid van Bantam had ingeoogst. Den $\mathbf{1} \boldsymbol{z}_{\text {den }}$ Augustus stuitte deze krïgsmacht bị Tjibodas op de vijandelijke voorhoede, die onder Aria Samboe en Mas Doela ann de overzijde eener breede rivier geposteerd was. Van Ossenberch waagde onversaagd alleen met zijue dragonders den overtocht en versloeg de opstandelingen, die met verlies van een vijftigtal dooden het veld ruimden, nog voordat het voetvolk hem over den stroom had kunnen volgen. Convert marcheerde den volgenden dag naar Sam 
pora 1, waar hij door een groote macht ter sterkte van 3000 man werd aangetast. Ki-Tapa toch had weinige dagen te voren den Moenara weder verlaten, om ziju beschermeling Ratoe Bagoes in deze benarde omstandigheden te hulp te snellen. Beider vereenigde macht moest ook hier het onderspit delven; hunne nederlaag was zoo beslissend, dat zị nauwelijks met het zesde deel van hun leger naar de zuidelijke bergstreken kouden vluchten. Bij deze schitterende zegepraal had Moestafa zich rocmrijk onder. scheiden, terwijl van Ossenberch door een verdwaalden musketkogel een lichte woud bekwam. Couvert trok daarop over Kalahan naar Lantjar, waar hij op verzoek van Moestafa een paar dagen verbleef en toen, getrouw aan den last van het opperbestuur, naar Bantam terugkeerde. Trouwens de indruk der laatste reeks van overwinningen was zoo groot op de Bantamsche bergvolkereu, dat Moestafa nu reeds over een inlandsche macht van 4000 man beschikken kon, zoodat de vervolging der rebellenhoofden in de voor Europeesche troepen minder tosgankelijke berglanden gerust aan hem alleen kon worden toevertrouwd.

Convert moest daarentegen in persoon toezien op de uitvoering van een bevel, dat der Indische Regeering bijzonder na aan het hart lag. Reeds toen Mossel in 1747 als Commissaris Bantam bezocht, had hij vruchteloos een beproefd middel gezocht ter uitroeiing der muskaatnotenboomen, die omstreeks Tjiassahan in het Anjersche Gebergte werden aangetroffen. ${ }^{2}$ $\mathrm{Nu}$ was daartoe het geschikte tijdstip aangebroken, zoodat de Gouverneur-Generaal, die reeds bij de installatie van den Prins-Regent op dit punt de aandacht gevestigd had, thans bij hetzelfde besluit, dat den krijgstocht naar het bimnenland goedkeurde, Couvert en Falck gelastte, dat de exsirpatie der notenboomen met kracht moest worden doorgezet. $\mathrm{N}_{\mathrm{a}}$ de door de troepen der Compagnie in zijn belang behaalde zegepralen kon de Prins-Regent zich bezwaarlijk tegen dien matregel aankauten. Met verscheidene Rijksgrooten ging hij dus met Convertouder geleide van 24 huzaren naar Tjiassahan, waar zonder verzet

1 Geen der hier bovengenoemde dorpen en andere namen, die in de ofticiëele stukken voorkomen, vond ik op de kaart van Bantam in Melvills Atlas, hoewel ze in de omgeving van den Karang moeten gezocht worden.

2 Verg. Mossels Rapport bij de Jonge, D. X, bl. 120, ook naar de daar opgegeven groeiplaatsen der notenboomen zoekt men te vergeefs in Melvill's Allas; de algemeene ligging blijkt echter duidelijk uit de opgave, dat zij omtrent vijf uur ten W.Z.W. van Bantam lagen. 
der bevolking 88 vruchtdragende boomen werden omgehouwen. Op deze wijze trachtte men te voorkomen, dat de zoo zorgvu'dig tot de Banda-Eilanden beperkte teelt der notenmuskaat ook in het Bantamsche zou aanwakkeren, van waar men bezwaarlijk den smokkelhandel met Benkoelen geheel kon tegengaan. 1

Ons rest nog kortelijk nategaan, wat er na Ki Tapa's nederlaag bij Tyilidoek op 13 Juli gedurende de latste helft van die en in de volgende maand voorviel op het oorlogstooneel langs de grens tusschen Bantam en Jakatra. Hoe beslissend die nederlaag ook was, had het rebellenhoofd eerst nog eenigen tijd de overgangen der Tjidani te Salabantar en Djampang bezet gehouden en zelfs een gelukkig viuchteloozen aanval op 's Compagnies post te Tjampea beproefd, maar was daarna, door van Ranzow met voor de troeper zeer vermoeiende marschen en contramarschen steeds achtervolgd, eindelijk in het laatst van Juli naar den Moenara teruggekeerd, van waar hij tot betere verdediging dier watuurlijke sterkte zijne vrouwen naar Djasinga zond. De luitenant-kolonel de Wendt, die kort daarop den kranken van Ranzow in het bevel over de troepen in de Jakatrasche Bovenlanden verving, zag weldra in, dat men door het bezet houden van de oevers der Tjidani en van de daar gelegen posten den vijand wel beletten kon, het grondgebied der Compagnie te verontrusten, maar dat men, om den opstand, welks kracht volgens hem te Djasinga zetelde, voor goed te bedwingen, de rebellen op eigen terrein moest aantasten. Nadat hij hiertoe de noodige machtiging bekomen had, marcheerde hij op 14 Augustus van Pondok Binda aan de Angkee naar Salabantar, waar hij zich met de colonne van Voltz vereenigde, de Tjidani overtrok en Katimagonas bezette. Den volgenden dag werd de Moenara van drie zijden beklommen, een ondernemen, waarbij men alleen de moeielijkheden van het terrein te overwimen had, daar de berg geheel onbezet was. De Wendt wilde toen over Kadoeang naar Djasinga trekken, in de hoop daar Ki Tapa aan te treffen. Toen het echter bleek, dat deze zich veel westelijker naar de zijde van den Karang gewend had, zay de Wendt van dit vooruemen af en bepaalde zich tot het verbrınden eener nieuwe negorij, die de opstandelingen bij den voet van den Moenara hadden opgericht. Ongelukkig liet hij op deze zoo belangrijke positie geen bezetting achter, misschien

1 Zie Converts Brieven dd. 7, 8, 17, 19, 21 en 29 Augustus en Secr. Resolutie van 12 Aug. 1751. 
omdat hij wegens de groote uabij Bantam opereerende troepenmacht te weinig manschappen onder zich had, en hij het gebied der Compragnie niet te zeer wilde ontblooten.

Het gewicht dezer fout bleek weldra, daar $\mathrm{Ki}$ Tapa en de Rebellen-Sultan na de op 18 Augustus geleden nederlaag bij Sampora met het geringe overschot hunner benden opnieuw den Moenara bezetten. Toen Voltz, die nog altijd te Salabantar gekampeerd was, hen van daar den 28sten Augustus wilde verdrijven, ondervond hij bij het beklimmen van den berg grooten tegenstand en moest spoedig terugtrekken, daar zijne inlandsche soldaten aan het muiten sloegen en weigerden zich verder bloot te stellen, zoolang hunne achterstallige gagie niet betaald was. Een nieuwe aanval op den Moenara, door Voltz op den 10den September beproefd, had geen beteren uitslag Intusschen had Convert gezorgd, dat Moestafa met zijue legermacht naar den Moenara oprukte, terwijl de Indische Regeering versterki g van de bemamningen der schepen en van de uit Bantam terugkecrende troepen naar de Bovenlanden zond. Met deze vereende macht van dragonders, matrozen, infanterie en met de troepen van Moestafa slaagde de majoor Roussel eindelijk deu 22sten September na een hardnekkigen en wanhopigen tegenstand in de vermeestering van den Moenara, die nu, om niet weder in de vorige fout te vervallen, door 60 Europeanen, 300 Javanen en 200 Bantammers bezet werd. 1

Hoe schitterend dit succes ook ware, was daarmede de kracht van den opstand nog lang niet gebroken, en moest zelfs het gebied der Compagnie nog last van de strooptochten der rebellen ondervinden. Humne hoofden toch, in de eerste dagen na de bestorming van den Moenara vruchteloos door de volgelingen van Moestafa nagezet, waren naar de zuidkust van Java geweken in de rechtstreeks onder de Compagnie staande westelijke landschappen der Preanger, die toen onder den naam van Segara Kidoel en Djampang bekend stonden. ${ }^{2}$ De poging, om langs de kust oostwaarts te trekken en zich met de opstande-

1 Zie Brieven van van Rauzow, dd. 21,22 en 24 Juli, van de Wendt, dd. 10 en 15 Aug., van Voltz, dd, 28 Aug. en 10 Sept. en van Roussel, dd. 22 Sept. 1751

2 Zie het Journaal van v. Imhoffs reis naar de Jakatrasche Boveulanden in 1744 (Bijdr. Inst., R. 2, D. VII, bl. 239 en 240) en de omstreeks dezen tijd gestelde Memorie van den Gouv.-Gen. Mossel over die gewesten bij de Jonge, D. $X$, bl. 244. 
lingen in Midden-Java te vereenigen, stuitte echter af op het verzet van de hevolking dezer streken. Ook in Tjandjoer en Bandong, waar aan de Regenten voor hunne tr uw aan de Compagnie cen aanzienlijke geldelijke belooning werd toegelegd, vonden de rebellen een even ongunstig onthaal. Eensklaps verschenen rij nu in het begin van December in het zuiderdeel van Buitenzorg. Terstond zond de Indische Regeering naar de daar geposteerde compagnie inlanders versterking van een veertigtal dragonders onder het hevel van den luitenant van Bacharach, die reeds den 7 den December de opstandelingen aan den voet van den Silak in hun kamp te Palasari overviel en eene gevoelige nederlaag toebracht, waarbij verschillende hunner hoofden omkwamen en de door de vermoeiende marschen in de onbegaanbare bergstreken van het gebruik zijner beenen beroofde Rebellen-Sultan door zijn volk gedragen moest worden, om niet in handen der onzen te vallen. Wel had het gerucht den uitslag dezer overwinning vergroot, daar de aanvankelijk als gesneuveld opgegeven Pangéran Madoera en Aria Soemboe spoedig weder in het veld verschenen; toch mocht de Indische Regeering de hoop koesteren, dat de opstand ten einde spoedde. De alan de nederlang ontsnapte vluchtelingen hadden zich namelijk teruggetrokken in het woeste, geheel onbekende zuidergebergte van Bantam, welks bewoners destijds nagenoeg onafhankelijk waren en evenals de tegenwoordige Badoeienen waarschijnlijk grootendeels de leer van den Islam nog niet hadden aange. nomen 1. Onder deze omstandigheden eindigde het jaar 1751 met gunstige vooruitzichten, vooral daar de gewezen Resident der Lampongs, Alexander van der Werp, weder bezit genomen had van den post aan de Toelang-Bawang en daardoor den invloed der Compagnie over deze peperrijke gewesten opnieuw verzekerd had 2.

Evenals bij zoo vele onzer oorlogen in Indië bleek het nu, dat weinig beschaafde volken, eenmaal in beroering gebracht, hoogst moeielijk weder tot rust en vrede terugkeeren. Niet lang

1 Althans van Breugel schrijft nog in 1787 (t. a. pl., bl. 320; verg. ook bl. 335): "hieronder moet men niet rekenen de zuidkant van Bantam, alwaar "volkeren woonen, die schoon onder het rijk gereekend worden te behooren, "nogthans den Koning van Bantam niet gehoorsamen en om haar verafgelegent"heid ook niet in den teugel kunnen gehonden worden."

2 Zie de Brieven van Bacharach dd. 7 en 12 Dec, Resolutie van 10 Dec. en de Alg. Brief aan Bewindhebbers van 31 Dec. 1751, de laatste bij de Jonge, D. X, bl. 187 . 
blecf de Tndische Regeering dan ook in onzekerheid omtrent de verdere plannen der rebellen-hoofden. Reeds in de eerste week van 1752 berichtte Vertholen, die nog altijd te Tangeran bevel voerde, dat Ki Tapa en Ratoe Bagoes met enkele volgelingen in een prauw de Tjidoerian tot Tanara waren afgezakt, schijnbaar om van daar naar de Lampongs over te steken. Dit voornemen werd niet ten uitvoer gelegd, waarschijnlijk op de tijding, dat de Compagnie reeds haar gezag over Zuid-Sumatra hersteld had; misschien ook was deze tocht alleen ondernomen, om persoonlijk den stand van zaken in de oostelijke districten van Bantam optenemen. Althans in de helft van Februari verschenen daar de beide hoofdopstandelingen met de ontijdig dood gewaande Pangéran Madoera en Aria Soemboe aan het hoofd eener bende van 800 man. Djasinga, Sadjira, Trogong en andere plaatsen wcrden achtereenvolgens door hen in de asch gelegd, waarop de bevolking van Pontang en Tanara opnieuw de partij van den opstand koos, zoodat de door den Prins.Regent aan. gestelde hoofden dezer beide districten naar Bantam moesten vluchten.

Ook daar namen de zaken aan het Hof een voor de Compagnie minder gunstigen keer. Convert, thans ook met de leiding der politieke aangelegenheden belast, nadat Falck, die reeds in Juli aan hevige koortsen leed, in September Bantam verlaten had, om met de retourvloot naar Nederland te vertrekken, klaagde voortdurend over den geringen steun, dien hịj van den zwakken Prins-Regent ondervond. Deze had niet alleen in weerwil van herhaalden aandrang verzuimd, de verdedigingswerken van het voormalige rebellenkamp bij Markasaua te doen slechten, maar stond geheel onder den invloed der hem als Rijksraden toegevoegde Pangérans Chamied en Radeen Soliman. Toen nu de tijding kwam, dat de volgens de hierboven besproken Resolutie van 18 Januari 1751 uit Ceilon teruggeroepen wettige Kroonprins in aantocht was, vreesden beide eerzuchtige roervinken, dat deze prins, die gewoonlijk in de officiëele stukken Pangéran Goesti genoemd wordt, den troon van Bantam zoude bestijgen, en dat zij daardoor hun oppermachtigen invloed aan het Hof zouden verliezen. Geen wonder, dat de omgeving van den Prins-Regent zich in deze omstandigheden tot de rebellen wendde en met hen onderhandelingen aanknoopte. Nauwelijks was Pangéran Goesti met zijn neef Monammed Ali, zoon van den eveneens uit Ceilon opontboden, maar intusschen over- 
ledeu Pangéran Bantau, den 25sten Februari 1752 op de reede van Batavia aangekomen, of de Indische Regeering, door Convert van de stemming te Bautam onderricht, zag zich genoodzaakt, erustig te overwegen, welke definitieve maatregelen men omtreut de kroon vam Bantam moest nemen.

Zoude dit rijk spoedig en duurzaam bevredigd worden - dat te wenschelijker was, omdat de toestand in Midden-Java na de nederlaig, die de majoor de Clercq op 12 December aan de Bogowonto geleden had, groote zorg en veel troepen vereischte dan moest de bevolking de overtuiging verkrijgen, dat de Compagnie geen plan had, Bantam bij haar gebied in te lijven. De aaustelling van eeu Sultan mocht niet langer verschoven worden, maar was te moeielijker, daar de Prins-Regent zoo weinig voor die hooge wardigheid geschikt was, en het van den anderen kant te zeer tegen de beginselen der Compagnie streed, hem, wiens persoonlijke trouw aan de Nederlanders boven verdenking stond, zonder voldoende aauleiding door den Kroonprins te vervangen, vooral diar men hem niet vooraf had verwittigd, dat de laatstgenoemde uit Ceilon was teruggeroepen. Het heette nu, dat Falck zulks verzuimd had, maar daar de Indische Regeering in hare politiek tegenover de inlaudsche vorsten gaarne een slag om den arm hield, acht ik het niet onwaarschijulijk, dat dit op haar last verzwegen was. Wat hier ook van zij, over het te nemen besluit werd den 28sten Februari uitvoerig door den Raad van Indië beraadslaagd. Bijna algemeen begreep men, dat het fatsoen vorderde, den Prins-Regent officiëel de aankomst van Pangéran Goesti te melden, onder bijvoeging dat dit opontbod reeds had plaats gehad, alvorens hij tot Regent was aangesteld. Tevens besloot men de beide Pangérans voorloopig aan boord te laten, totdat nadere tijding uit Bantam outvangen was. Men vond het toch al te gevaarlijk, Pangéran Goesti te Batavia aan den wal te laten komen, zoolang niet bepaald was, welken rang men hem zoude toekenuen, daar meu te Batavia moeielijk kon beletten, dat inj zich heimelijk naar Bantam begaf en daar dan door de gehechtheid, die bij de inlandsche bevolking voor zijn persorn mocht verwacht worden, groot aanzien verkieeg, voordat zijne verhouding en verplichtingen jegeus de Compagnie juist omschreven waren '.

1 Zie Brieven van Vertholen dd. 8 Januari, 18 en 19 Febr., van Convert dd, 22 en 25 Febr.; Secr. Res. van 28 Februari 1752. 
Nauwe ijks hadden de rebellen-hoofden vernomen, wat or aan het Bantansche Hof omging, of zij ontruimden de oosterdis. tricten en trokken westwaarts, om dichter bij de hoofdstad te zijn. Ki Tapa bezette nu den nabij den Karang gelegen berg Sahari (den uitgedoofden vulkam Poelasari), terwijl Ratoe Bagoes met een bends van 500 man het westerstrand boveu Tjiringin afliep. Weldra hadden beide een leger van 4000 man vereenigd en marcheerden daarmede naar Serang. Hier had de Prins-Regent cene troepenmacht opgesteld onder den in October opgetreden Rijksbestierder Aria Koesoema di Ningrat en ziju broeder Pangéran Radja Santika, die de rebellen terugsloeg, echter niet zonder groote verliezen, daar de dappere Moestafa sneuvelde, welk ongeval eene krachtige vervolging der opstandelingen belette. Teven: berichtte Convert, dat het volk van Bantam opgetogen was over de verwachte terugkomst vin den Kroonprins. De Prins-Regent werd door zijne bejde invloedrijke Rijksraden zoo nauw bewakt, dat men hem bijna nimmer alleen kon spreken. Eens had hij echter een geschikte gelegenheid te baat genomen, om Convert te verzekeren, dat hij zich in alles an de besluiten der Indische Regeering onderwierp en zelfs gaarne van het bestuur afstand deed, mits hij overeenkomstig zijne waardigheid vin oud-regent behoorlijke inkomsten bchield. Ook de in dezen tijd wegeus zijne ervareudheid in het Javaansch 1 naar Bantam gezonden opperkoopman Jan van Suchteleu, om na Convert's vertrek liet bestuur over dat gewest te voeren, bevestigde dit alles, maar drong tevens krachtig op de verwijdering aan der Pangérans Chamied en Soliman, waartegen te minder bezwaar bestond, omdat zij door hunne afpersingen bij de bevolking zoo gehaat waren, dat zij zich niet buiten de hoofdstad durfden wagen, terwijl het rijk niet tot rust zou komen, zoolang zij hunne intrigues ongestoord aan het Hof voortzetten.

$\mathrm{O}_{\mathrm{p}}$ de on:vangst dezer berichten besloot de Indische Regee. ring na gezet overleg bij Resolutie van 13 Maart, dat de twee gevaarlijke Rijksralen naar Batavia vervoerd zouden worden, de Prius-Regent tot Sultan zou worden aangesteld, eu dat Pangéran Goesti door zıjue erkenning als Kroonprins de zekerheid der troonsopvolging zou verkrijgen. Ter uitvoering van dit besluit ell on de door den oorlog geheel veranderde verhouding van Bantam tot de Compagnie door het siuiten van een nieuw con-

1 De Sultans van Bantam en hunne omgeving spraken geen Soendaneesch, maar Javaansch 
tract op beteren voet te regelen, werd de Extra-ordinair Raad van Indië Loten als Commissaris naar Bantam gezondeu 1. Zes dagen later verkreeg Loten van den Raad van Indië de Instructie, waarnaar hij zich in deze onder de bestaande omstandigheden even delicate als hachelijke zending moest regelen, met het concept voor het verdrag, waarbij de Prins-Regent als Sultan zou worden erkend. In de praeambulen dezer Acte van Investituur werd uitvoerig gerecapituleerd, wat er sinds 1748 in het rijk van Bantam was voorgevallen : dat de krankzimnigheid van den nar Ambon vervoerden Sultan de Compagnie genoodzaakt had, dit bondgenootschappelijk rijk tot diens dood of herstel onder Hare bescherming en bewaring te nemen; dat de Koningin-Regentesse door hare hoovaardij eene openbare rebellie verwekt had, die zich met uitzondering van de hoofdstad weldra over het geheele rijk en de overzeesche onderhoorigheden op Sumatra uitstrekte en niet dan na groote inspanning en opoffering door de wapenen der Compagnie was bedwongen; dat het tegenwoordig bestuur van een Regent over Bantam, welk rijk van oudsher door Sultans geregeerd was, "door qualyk geintentioneerden als maar tem"poreel of onbestendig zoude kunnen worden gedecrieerd, om "onder de goede patriotten eene bedugting voor nieuwe ver"anderingen te verwecken en voeden, en de onnoselen daar"door van haren verlosser de Compagnie afkeerig te maken "; dat de laatste Sultan door de zwakheid zijner geestvermogens nog steeds voor de regeering ongeschikt was, zoodat de Compagnie, daar Bantam thans bij wijze van conquest onder hare opperheerschappij gebracht was, om in dit rijk rust en vrede te herstellen, en uit genegenheid voor de familie van wijlen den grooten vorst Sultan Hadji Aboe'n Natsr Abdoe'l Kahhaar, Bantam als een vrij leengoed opdroeg aan den Prins-Regent, om het rijk onder den titel van Padoeka Siri Sultan Aboe'l Maäli Mohammed Wacioel Haliemien te besturen. In de een en twintig artikelen dezer concept-acte werd vooreerst bevestigd, hetgeen de Compagnie reeds bij vorige verdragen van Bantam verkregen had: zooals de uitsluiting van vreemde Europeesche natiën, het monopolie van den peperhandel, de uitlevering der overloopers uit het grondgebied der Compagnie,

1 Zie Brieven van Convert van 3, 5 en 14 Maart; van v. Suchtelen dd. 10 Maart; Secr. Resolutie van 13 Maart en Alg. Brief aan Bewindhebbers dd. 31 Maart 1752 . 
het bestuur over de te Bantam gevestigde Chineezen en vrecmdelingen uit andere landen van deu Archipel, eindelijk de afstand der strook gronds bewesten de Tangeransche Rivier, de zoogenaamde Grending 1, die van het voor Bantam liggende eiland Pandjang en van de forten Speelwijk en Karang Hantoe met de daartoe behoorende gronden. Daar Bantam echter bij deze gelegenheid een leenrijk werd, werd nader vastgesteld, dat de Sultan jaarlijks een gezantschap naar Batavia zou zenden met een geschenk van 100 baar peper, als hommage van den vassal aan zijn leenheer; dat hij buiten voorkemnis der Indische Regeering geen nieuwe versterkingen in zijn rijk mocht oprichten, welke harerzijds daartoe ten allen tijde het recht behield; evenzeer kon zị desverkiezende het getal der suikerplantages in het Bantamsche beperken, waar voortaan alle handel in koffie verboden was. Laastelijk werd uitdrukkelijk bepaald, dat het leen van Bantam aan den leenheer vervallen zou, als de Sultan of iemand van zijnentwege ooit de wapens tegen de Compagnie opvatte. Ook moest hij met de Prinsen van den bloede en de Rijksraden dit contract bezweren, onder verzekering, dat hij op den troon zou gehandhaafd worden, zoolang de bepalingen van het verdrag getrouw werden nagekomen. Eveneens zouden de tegenwoordige ministers des Sultans hunne ambten behouden, wauneer de vorst en de Compagnie dit ten beste van het rijk dienstig oordeelden. Hoezeer de taak van Loten door een en ander binnen enge grenzen was omschreven, had hij evenwel volmacht, op verzoek van den PrinsRegent geringe wijzigingen in het verdrag te brengen.

Reeds den 15den Maart kon Convert berichten, dat hij de twee aan het Bantamsche Hof zoo gevaarlijke Pangérans Chamied en Soliman had opgepakt en naar Batavia verzonden, vanwaar zij een half jaar later met den nog altijd te Edam gënterneerden afgezetten Kroonprins Sjarief Abdoella naar Banda werden vervoerd. Veel gronter bezwaren ondervond daarentegen Loten, die den 26sten Mart met de beide uit Ceilon teruggekeerde Prinsen te Bantam aankwam, bij de uitvoering der hem toevertrouwde commissie. Wel makte de Prins-Regent en zijn Rijksraad geen aanmerkingen op den hoofdinhoud van het concept-verdrag, dat Bantam in een leenstaat zoude herscheppen,

1 Zie de reeds vroeger aangehaalde Memorie van Mossel over Jakatra (de Jonge, D. X, bl. 243). 
en opperde men aan het Hof aanvankelijk slechts bedenkingen over enkele punten van oudergeschikten aard, zooals over de regeling der aan de Compagnie te vergoeden oorlogskosten en over de vraag, of al de door Chineezen en oostersche vreemdelingen bij Bantamsche moeders verwekte kinderen onder de jurisdictie der Compagnie zouden blijven. Nauwelijks had Loten echter aan die wenschen toegegeven, of het bleek hem, dat vele aanzienlijken uit de omgeving van den Regent tegenzin tegen het sluiten van het tractaat betoonden en zelfs het tot stand komen daarvan hoopten te verijdelen, toen de opstandelingen in het begin van April eensklaps weder met aanzienlijke macht op twee uur afstands vau Bantam verscheneu waren. $\mathrm{Na}$ de in de vorige maand bij Serang geleden nederlaag hadden zij zich toch eerst oostwaarts gewend, naar het scheen met het plan, om den Moenara weder te bezetten of 's Com. pagnies post te Tjampea aan te tasten; zoodra zij eehter verwittigd waren, dat de outevredenen aan het Hof zich waarschijulijk bij hen zouden aansluiten, waren zij ijlings over Oenderandir naar de nabijheid der hoofdstad getrokken ${ }^{1}$. Niettemin verkreeg Loten door energiek optetreden en met af brekiug der onderhandelingen te dreigen, dat de Prins-Regent den ssten April al de artikelen der concept-overeenkomst met de daarin op diens weusch gebrachte wijzigingen goedkeurde. Alvorens echter de plechtige onderteekening van het verdrag en de kroning van den nieuwen Sultan kon plaats hebben, had de Kommissaris nog andere moeielijkhedeu te vereffenen. Allereerst was het dringend noodzakelijk, dat de financiëele positie van den nieuwen Kroonprins voor het vervolg op duurzamen grondslag geregeld werd, waartoe de gierige Regent noode de vereischte inkomsten wilde afstaan. Ook had de terugkomst van Pangéran Goesti te Bantam veel narjver en ontevredenheid gewekt bij hen, die tot dusver den zwakken Regent naar hun wiliekeur bestierden. Zelfs had de Kroomprius, die gaarne terstond in plaats van zijn oom den troon wilde beklimmen, warrop hij, zoo van vaders als moeders zijde een kleinzoon van Suitan Hadji, de meeste aanspraak had, zijnerzijds eveneeus verbindingen met de rebeilen aangeknoopt en, om zoo mogelijk de Nederlandsche onderhandelaars te intimideeren, de voor Bantam liggende benden van 1200 tot 10,000 man vergroot.

1 Verg. de Brieven van Vertholen dd. 12, 16 en 31 Maart 1752. 
In een hoogst belangrijk schrijven van 12 April gaf Loten aan de Indische Regeering een levendig tafereel van de op dit oogenblik aan het Bantamsche Hof bestande verwikkelingen en van de bezwareu, die hij daardoor in het volbrengen zijner zending ondervond 1. Pangéran Goesti klaagde toch, dat men een poging had aangewend, om hem te vergiftigen, terwijl hij de eerzuchtige gemalin van den Regent voor de aanstookster hield, aan wie hij het evenzeer toeschreef, dat zijne gedurende zigne ballingschap te Bantam achtergebleven echtgenoote plotseling overleden was, toen zijne terugkomst aldaar bekend werd. Loten wist niet, wat hiervan te denken: den Regent hield hij in dit opzicht voor geheel onschuldig; ook had hij geen voldoenden grond, om diens gemalin te verdenken; andere ontevredenen aan het Hof konden eene komedie gespeeld hebben, on de twee vorsten legen elkander op te zetten; misschien was de geheele zaak slechts een verzinsel van den Pangéran, om daardoor te eerder zijn doelwit, de kronn van Bantam, te bereiken. Daar echter beide prinsen even welgezind waren jegens de Compagnie, en de zwakke Regent zich op denduur bezwaarlijk in de regeering zou handhaven tegen den eerzuchtigen Pangéran, die op den steun der bevolking kon rekenen, welke de ander door rijne gierigheid van zich vervreemd had, achtte Loten in overeenstemming met Convert en van Suchtelen het wenschelijk, bij den Regent een poging aan te wenden, dat deze onmiddellijk na zijue kroning tot Sultan den troon aan den Pangéran zou afstaan.

Dit schrijven uit Bantan werd in den Raad van Indië met zorg overwogen. De Regeering te Batavia was toch op dat ongenblik in groote verlegenheid wegens den ongunstigen loop v:un den oor log in Midden-Java, waar Mangkoeboemi omstreeks de helft van Maart naar de noordkust op het gebied der Comp:ignie was doorgedrongen en zelfs geheel Pekalongan veroverd had, terwijl de aanvoer van nieuwe troepeu uit Nederland zich als gewoonlijk weder zeer deed wachten. Hoewel het in gewone omstandigheden meer met de geijkte staatkunde der Compagnie strookte, rich door den bestaanden naijver tusschen den Sultan en den aangewezen troonopvolger een krachtigen invloed op de zaken in Bantam te verzekeren, scheen dit anders zoo beproefde middel thans

1 Wegens het interessante van den inhond wordt deze brief, hoezeer door groote haast buitengewoou slordig gesteld, hierachter in ziju geheel als bijlage opgeноmen, 
te gevaarlịk en de onmiddellijke verheffing van den bij de bevolking beminden Pangéran tot Sultan vooral daarom gewenscht, ondat men de hoop mocht koesteren, dat de opstand daardoor zijn grootste kracht zoude verliezen. Derhalve werd Loten bij Secrete Resolutie van 14 April gemachtigd, den Regent tot den troonsafstand over te halen, maar onder uitdrukkelijk beding, dat dit alleen mocht plaats hebben, indien de oude man, aan wien de Compagnie zooveel verplicht was, goedschiks tot dien stap overging. Dwang achtte men toch onstaatkundig, omdat zulks een slechten indruk op den inlander zou maken, terwijl de Pangéran, hoe aangenaan hij het aanvankelijk vindeu mocht, dat hị nu reeds den troon beklom, daaruit later allicht argwaan kon krijgen, dat de Compagnie hem, zoodra het in haar belang was, eveneens van den troon zou afdringen. De toekomst heeft later de juistheid dezer overwegingen ten volle bevestigd; ook in dit geval bleek de gulden stelregel: Honesty is the best policy, een waarheid.

Tnmiddels had Loten zijne onderhandelingen met het Bantamsche Hof ijverig voortgezet, ook over den oinvang der op den dag der kroning van den nieuwen Sultan aan de opstandelingen uit te vaardigen amnestie. Daar hij echter terecht bezorgd was, dat die plechtigheid verstoord kon worden, wanneer het met de Prinsen van den bloede en de Rijksgrooten op de passerbaan vereenigde volk, met ondersteuning van heimelijk in Bantam toegelaten rebellen, tegen den zin der Cumpagnie Pangéran Goesti als Sultan uitriep, was het zaak, vooraf de opstandelingen uit de nabijheid der hoofdstad te verdrijven. Een detachement troepen tastte derhalve den 14,den April Ki Tapa aan en verdreef dezen van Kanari naar Markasana, waarbij hij zulke verliezen leed, dat hij den volgenden dag de troepeu niet in laatstgenoemde plaats afwachtte, maar over Serang naar Lantjar terugweek. De hoofdınacht der opstandelingen trok nu oostwaarts naar Djasinga en legde ouderweg Pontang in de asch, terwijl Ki Tapa voorloopig met een bende van 800 man in de nabijheid van den Karang achterbleef, on ware het hem mogelijk nog de kroning te verhinderen. Bij den opmarsch der troepen naar de verlaten stellingen der opstandelingen nabij Bantam bleek het duidelijk uit de talrijke goed bebouwde rijstvelden in deze vruchtbare landsdouwen, dat men den vijand alleen door wapengeweld, nict door gebrek ann levensmiddelen tot den aftocht had kumnen nondzaken. 
Ook de onderhandelingen kregen nu den gewenschten uitslag. Vooreerst werd an de reeds gesloten overeenkomst een separaat artikel toegevoegd, waarbij het inkomen van den Kroonprins, die als zoodanig den titel van Pangéran Ratoe Aboe'l Mofachir Mohammed Arief Zeince'l Abedien verkreeg, werd vast. 'gesteld op een vierde der na aftrek van de jaarlijks aan de Compagnie terugtebetalen oorlogskosten overblijvende zuivere inkomsten des rijks. Tevens werd bepaald, dat de Sultan, wanneer hij de kroon aan Pangéran Goesti afstond, levenslang hetzelfde inkomen zou genieten. Bij een ander geheim artikel, waarop de Indische Regeering zeer had angedrongen, verbond de Sultan zich, dat hij, zoodra het rijk van Bantam tot ziju vorige macht en bloei was teruggekeerd, de Engelschen zou verdrijven uit de oude onderhoorigheden van Bantam in de westelijke Lampongs en het monopolie der daar wassende peper eveneens aan de Compagnie zou gumnen. Bij hetgeen thans van den verderen loop der geschiedenis bekend is, verwekt de lezing dier voorwaarde onwillekeurig een grimlach. Volgens de Memorie van Gollenesse hadden de Engelschen toch reeds in 1734 van Benkoelen uit de afdeelingen Tallo eu Manna bezet, en in 1753 breidden zij zich verder zuidwaarts over Kauer en Krohé tot aan Sumatra's zuidwestpunt uit. Bovendien hadden zij in 1751 Natal en vijf jaar later Tapanoeli bemachtigd en dus ook benoorden de oude bezittingen der Compagnie op de Westkust post gevat. Bedenkt men eindelijk, dat de Indische Regeering dertig jaar later tijdens den oorlog met Engelaud deze posten te Padang, Priaman, enz. zonder slag of stoot aan haar alouden concurrent in de Oostersche Zeeën moest overgeven, dan gelijkt dit geheim beding sprekend op het verkoopen der huid van den ongeschoten beer, en was de vorst van Bantam nog het verstandigst, die blijkens de door hem gestelde reserve de mogelijkheid der uitvoering zeer scheen te betwijfelen.

Nadat de verschillende bepalingen van het nieuwe tractaat met Bantam dus eindelijk met wederzijdsch goedvinden waren vastgesteld, werd dit den 17 April 1752 , den dag der kroning van den Regent tot Sultau en van den Pangéran tot Kroonprins, in behoorlijken vorm bekrachtigd, zonder dat die plechtigheid van den kant der opstandelingen eenige stoonis ondervond 1.

1 Het Contract met Bantam van 17 April 1752 was niet op het Rijksarchief en is dientengevolge niet opgenomen in het tiende deel van de Jonge. De

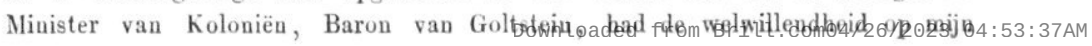


Alvorens naar Batavia te vertrekken, had de Commissaris Joten drie dagen daarna een laatste bijeenkomst met den nieuwen Sultan, waarbij hij den vorst mededeelde, dat hij-door de Indische Regeering gemachtigd was, zija verblijf bimen Bantam te verlengen, wanneer de Sultan nu reeds de kroon an den Pangéran mocht willen afstaan. Daar echter de oude vorst door dit voorstel zeer ontroerd werd, moest Loten, overeenkomstig hetgeen hem was voorgeschreven, van verderen aandrang afzien. Gelukkig was de Kroouprins, lie eerst zoo hoog opgaf van den invloed, dien hij op de rebellen uitoefende, thans ten hoogste op hen verbitterd, daar zij in weerwil zijner bevelen bij hun aftocht uit de nabuurschap van Bantam behalve het verbranden van Pontang allerlei gewelddadigheden hadden bedreven. Des te meer berouwde het hem dat hij, eveuals de Sultan en de meeste Rijksgrooten er op had aangedrongen, geen der hoofden des opstands van de uit te vaardigen amsestie uit te sluiten. Slechts noode had de Indische Regeering er in toegestemd, dat vergiffenis zou worden verleend an $\mathrm{Ki}$ Tapa, die niet alleen als de eigenlijke aanstoker der rebellie moest worden beschouwd, maar op wien men vooral gebeten was, omdat hij

verzoek een afschrift van dit verdrag uit Indië te ontbieden en dit met de Instructie voor Loten, de Concept-overeenkomst en andere toelichtende bescheideu, waaraan het bovenstaande ontleend is, in mijne handen te stellen. De tekst van het Contract zal met het Rapport, dat Loten den 28sten April over zijne zending aan den Raad van Indië uitbracht, door mij worden opgenomen in het volgende deel van de Jouge's werk. Dit belangrijke tractaat toch, het eerste, waarbij de vorsten van Bantam zich als vassallen der Compagnie erkenden, mag in die gewichtige bronnenverzameling te minder ontbreken, omdat onze nienwere geschiedschrijvers met het bestaan van dit verdrag in het geheel niet bekend waren, of althans den inhoud slechts zeer onvolledig kendeu. Zoo spreken vau Kampen eu Lauts er met geen enkel woord van; ook Hageman is op dit punt zeer verward. In zijne Geschied, van Java (1). I, bl. 214) houdt hij Sultan Wacioel Haliemien voor den uit Ceilon teruggekeerden Kroonprins, terwijl hij in een later opstel: Java op het einde der achttiende eeuw (Tijdschr. Bat. Genootsch., D. IX, bl. 890) zelfs beweert: "Banten was het "eenige gewest van Java, dat nimmer, zoolang de Compagnie bestond, geconquesteerd, overwonnen verklaard of afgestaan werd", hocwel het hem bekend was, dat Bantam in dezen tijd een leen der Compagnie werd. llet bestaan en het belang van dit contract worlt vermeld door van Breugel, zoo ook door de Hollander, Meinsma eu Veth, mar de juiste dagteekening wordt nergeus en het jaar gewoonlijk verkeerd opgegeven, terwijl de inhoud zoo weinig bekend was, dat de beide latstgenoemde schrijvers ten onrechte verzekeren, dat de Lampongs bij deze gelegenheid aan de Compagnie werden afgestaan. Als onderhoorigheid van het leen Bantam kwamen deze gewesten natunrlijk onder het oppergezag der Comlagnie, maar zij bleven toen als voorbeen onder het bestumr der Sultans. 
een jaar te voren door zijne brieven an de bedienden te Speelwijk smadelijk elke toenadering tot de Compagnie had afgeslagen en zelfs haar gezar in honende bewoordingen had uitgedaagd. Daar het evenwel niet te loochenen vicl, dat $\mathrm{Ki}$ Tapa, het eenige stantkundige hoofd van den opstand, deu Rebellen-Sultan van vele wreedheden had teruggehouden, en daar het te vreezen was, dat zijne uitsluiting van de ammestie de toenadering der andere hooflopstanatlingen zou belemenen, had de Rand van Indië den Commissaris Joten gemachtigd, ook op dit punt aan den aandrang van het Bantansche Hof toe te geven.

Hoezeer dus op den dag der krooning bij plechtig manifest veruitlenis zonder eenige uitzondering was afgekondigd an de rebellen, die zich binmen een bepaalden termijn onderwierpen, had de uitvaardiging dezer algemeene ammestie op zich zelf weinig gevolg. Veel grooter invloed mocht daarentegen verwacht worden van de krooning zelve en van de verheffing van Pangéran Goesti tot Kroonprins. Daardoor toch verkreeg de inlandsche bevolking van Bantan de zekerheid, dat het Sultansbestunr als van ruds zou blijven voortbestaan, en dat de wettige erf. genaam der kroon na een niet al te larg tijdsverloop zijn zwakken afgeleefden oom op den troon zou vervangen, hetgeen an de rebellie hare voornaamste levenskracht moest ontuemen. Gedurende twee manden handhaafden Ki Tapa en Ratoe Bagoes zich evenwel nog aan den bovenloop der Tjidoerian. De Indische Regeering vleide zich — een bij onze oostersche oorlogeu zoo dikwijls voorkomend geval - zelfs te vroes met het spoedige verloop van den opstand, toen zij in den aanvang van Jumi aan Bewindhebbers berichtte, dat de rebellen nog in de bovenlanden rondzwierven, maar dat hun aan'iang niet noemenswaard meer was. Om hen in ieder gevil uit de onmiddellijke nabijheid van 's Compagnies grondgebied te verdrijven, was luitenant Gille, de bevelhebber van den post aan de $\mathrm{Kwal}$, met een troepen macht over de zoo even genoemde rivier het binnenland ingetrokken, waar hij te Sadjira kampeerde. Nu echter verliet Ki Tapa den 26sten Juni deze oostelijke streken en marcheerde in ijlmarschen over Bombang, Priang, Pairokojang en Lantjar naar Tjiringin, waar hij zich niet ontzag, eenige matrozen van een Deenschen China-vaarder gevangen te nemen. Ook werd hij hier door een twretal Frumsche schepen van oorlogsbchoeften

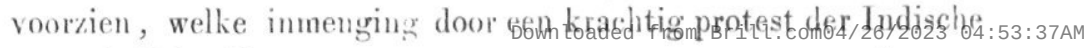


Regeering gevolgd werd, mar tevens aantoonde, hoe geva: rlijk het was, dat $\mathrm{Ki}$ Tapa zich in deze zeeplaats ophield, van waar hij zoo licht nar de Lampongs kon overstekeu. Eene compagnie Europeanen, verzeld door eenige Bantamsche troepen, werd dus uit de hoofdstad derwants gezonden en noodzaakte $\mathrm{Ki}$ Tapa door een veldslag Tjiringin te ontruimen. Door de Bantammers onder Pangéran Radja Nagara achtervolgd, leden de rebellen den 29sten Juli bij de negorij Panadegan, wier juiste ligging mij onbekend is, een nieuwe nederlaag. Het was een bloedige strijd, die aan beide zijden veel dooden en gekwetsten kostte; aanvankelijk wist men zelfs niet, werwalarts Ki Tapa gevlucht was.

Het duurde echter niet lang, of de onvermoeide partijganger viel eensklaps weder in de Jakatrasche Bovenlanden, die door de vele bezettingen, welke de oorlog in Midden-en OostJava voortdurend eischte, thans nagenoeg geheel van troepen ontbloot waren. Te vuur en te zward verwoestte $\mathrm{Ki}$ Tapa nu het Buitenzorgsche, de velden der weinige jaren te voren aan het Warme Bad (Tjipaunas) gevestigde Europeesche boeren 1 en de onstreken van Tjandjoer en Tjiblagong, zoodat de Indische Regeering later de bewoners dier zoo geteisterde gewesten van het opbrengen der verschuldigde contingenten moest ontheflen. Eene hem ijlings uit Batavia achterna gezonden compagnie drigonders overviel den stoutmoedigen roover te Bandong, watar deze 100 man verloor en al de tot dusver behaalde buit met de Deensche schepelinges in handen der Nederlandsche troepen viel. Na deze geweldige nederlag verdeelden de hoofden der opstandelingen zich. Pangéran Madoera vluchtte met Ratoe Siti en andere vrouwen van den verbannen Sultan westwaarts naar de bergstreken van Bantam en ouderwierp zich in October aan de Compagnie en den nieuwen Sultan. Ki Tapa daarentegen volvoerde nu met Ratoe Bagoes zijn vorig plan, om zich met de opstandelingen in Midden-Java te vereenigen. Eerst trokken zij naar Banjoemaas en, toen zij daar door onze troepen verdreven waren, met slechts weinig volk door Bageleen naar Mataram. Het gerucht, dat Ratoe Bagoes op dien tocht het leven liet, bleek later onjuist, maar Ki Tapa's naam verdwijnt voortaan uit de geschiedenis. Hoogst waarschijnlijk vond deze rustelooze strijder zijn

1 Zie over deze kolouisatie te Tjipannas de boven aangehaalde afzonderlijke studie van de Jonge en Mossels Rapport over Jakatra bij de Jongre, D. $\mathrm{X}, \mathrm{bl} .257$. 
dood in den nog steeds op Java voortwoedenden oorlog. Eerst nu tegen het laatst van 1752 kou de geweldige Bantamsche opstand als geeindigd beachouwd worden. De brigadier Convert verliet thans Bantam met de daar overtollige troepen en droeg het beheer aldaar aan van Suchtelen over, die in Augustus 1753 den sedert eenige jaren aan deze betrekking verbonden rang van Commandeur verkreeg. Geleerd door de ondervinding van den laatsten tijd, vestigde de Indische kegeering nog in November 1752 eene kleine bezetting te Tjiritta nabij Tjiringin, terwijl zij in Maart van het volgende jaar merkpalen met haar wapen en dat van Bantam liet plaatsen op het eiland Krakatiuw en andere veelal door vreemde schepen bezochte waterplaatsen. Ook werd, om te beter tegen de handelingen der Engelscheu op Sumatra te waken, haar post in de Lamongs van den afgelegen Toelang Bawang naar de IampongBaai overgebracht 1 .

Tot behoud der door de Compagnie met zoo buitengewone inspanning en opoflering verkregen bevrediging van het Bantamsche rijk bleef het evenwel dringend noodzakelijk. dat het Sultansbestuur in krachtiger handen kwam dan die van den zwakken afgeleefden Wacioel Haliemien. Eindelijk had ook deze vorst ingezien, dat zijn leeftijd en ziekelijk gestel hem voor de regeering minder geschikt makkten, en nam hij, ongetwijfeld zeer in dat plan versterkt zoowel door van Suchtelen als door den eerzucitigen Kroonprins, het kloek besluit, ten behoeve vin den laatstgenoemde van den troon afstand te doen. Het gezantschap, dat overeenkomstig de bepalingen van het nieuwe contract den 1sten Juni 1753 onder den Rijksbestierder Kiai Aria Koesoema di Ningrat te Batavia verscheen, om de Com. pagnie als leenheer te huldigen, was tevens de overbrenger van een brief des Sultans, waarbij hij op dit besluit de goedkeuring der Indische Regeering verzocht. Zonder lange aarzeling gaf de Raad van Indië bij Resolutie van den 29sten dier maand aan dit verzoek gehoor en benoemde tevens zijn medelid, den lateren Gouverneur-Generaal van der Parra, tot Commissaris en Plenipotentiaris, om den nieuwen Sultan van Bantam te installeeren. Wegens de Mohammedaansche poeasa kwam van der Parra eerst

1 Zie Resoluties van 3 en 14 Juli, 1 Aug., 30 November en 30 December 1752 en van 6 Maart 1753; Alg. Brieven aan Bewindhebbers van 6 Juni, 5 Oct. en 31 Dec. 1752, de laatste bij de Jonge, D. X, bl, 193. 
den 29sten Augustus te Bartam, bij deze plechtige zending moler anderen verzeld door van ()ssenberch, die door zijne krijgsbedrijven in $175 \mathrm{I}$ de Bantamsche toestanden van nabij had leeren kennen. Hoewel de oude vorst wel van den last en de beslommeringen der regeering ontslagen wilde zijn, trachtte hij niettemin, vooral ten behoeve zijner kinderen, wier vijftal eerlang met een zesde verineerderd zou worden, van de aan de Sultanswaardigheid verbonden inkomsten en voordeelen zooveel te behouden, als maar eenigszins mogelijk was. Eerst na langdurige en tijdroovende onderhandelingen met den Sultan en den Kroonprins slaagde vau der Parra er in, beider goedkeuring te verkrijgen op deze bepalingen, dat de eerstgenoemde na zijne aftreding, zooals reeds in het vorige contract vastgesteld was, zoude genieten een vierde deel der zuivere inkonsten des Rijks, maar ook dat ten zijnen behoeve 3250 heeredienstplichtigen van hofdienst verschoond zouden worden, terwijl tevens de lijst werd opgemaakt der kostbaarheden, die de oud-Sultan levenslang in zijn berit zou houden. Behalve deze bepalingen en de vaststelling vau het getal der Bantan che suikermolens op vier, was het nieuwe contract, dat den 22sten September onderteekend werd, geheel gelijkluidend aan dat van het voorgaande jaar. Drie dagen later geschiedde de plechtige krooning van den jongen Sultan onder den titel Aboe'n Natsr Mohammed Arief Zeinoe'l Asjekien. Bij deze gelegenheid hield van der Parra een indrukwekkende toespraak tot den jongen vorst, waarbij hij hem erustig op het gemoed drukte, hoevele weldaden de Compagnie hem bewezen had. Geroerd antwoordde de Sultan, dat hij die nimmer zou vergeten en zijne dankbaarheid zou toones door een getrouwe vervulling zijner verplichtingen jegens de Indische Regeering. Inderdaad moet erkend worden, dat Zeinoe'l Asjekien, wat er ook later op de behandeling zijner onderdanen en in zijne verhouding tot de talrijke prinsen vau den bloede viel aan te merken, tot zijn overlijden een trouw vassal der Compagnie gebleven is. Alvorens Bautum te verlaten, had van der Parra, daar er bij Tjiassahan weder muskaatnoten gevonden waren, nog krachtig op de uitroeing dier specerij-boomen aangedrongen, terwijl hij na zijne terugkomst te Batavia in het Ripport, dat hij over zijne volbrachte zending a:n de Indische Regeering indiende, uitvoerig verslag gaf, welke herstellingen aan de versterkingen en gehouwen der Co!npagnie binnen Bantam

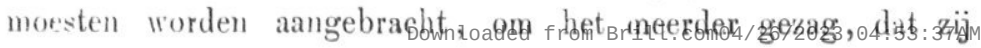


door de nieuwe contracten in dit rijk verkregen had, te beter te kummen handhaven. 1

Zoo was dan eindelijk na veel moeiten en zorgen de rust in Buntam geheel hersteld, en het oppergezag der Compagnie over dit rijk op duurzamen groudslag gevestigd. De enkele onlusten, die nog voorkwameu en als de laatste stuiptrekkingen van den opstand moeten beschouwd worden, waren van geringe beteekenis. Dus werd nog in het laatst van 1753 zekere Maas Boeang, een zeeroover uit Cheribon, die zich voor den wettigen erfgenaam van den Bantamschen troon had uitgegeven, opgepakt en op verzoek des Sultans met afgesneden neus en ooren door diens hofstad rondgevoerd. Een groot jaar laier, in den aanvang van 1755 , verscheen de gewezen Rebellen-Sultan eensklaps weder op het tooneel, maar reeds binnen een maand liet Ratoe Bagoes Boeang op het Prinseneiland het leven. T'oen een zijuer zoons Si Tjongleng of Tjangliang vijf jaar daarna met Pangéran Midoera, wiens werkzaam aandeel in den grooten opstand hierboven herhaaldelijk vermeld werd, een nieuwe poging deed, om onlusten in het Bantamsche te verwekken, vielen beiden spoedig in handen van het bestuur en werden met Ratoe Siti, die na den dood van haar tweeden gemaal met den Pangéran gehuwd was, verzonden naar de Banda-Eilanden, sedert de laatste jaren het gewone verbanningsoord der voor de rust van Bantan gevilarlijke personen. Omsireeks denzelfden tijd in April 1760 overleed de oud-Sultan Wacioel Haliemien, waardoor zijn opvolger in het volie genot kwam van de inkomsten der kroon 2. De politieke rust in het rijk Bantam, voor de Compagnie wegens de nabijheid van Batavia van zoo buitengewoon groot belang, bleef ongestoord, zoolang Zeinoe'l Asjekien en diens zoon en opvo!ger Alioeddien regeerden. Gedurende een halve eeuw tot het overlijden van laatstgenoemden vorst in 1802 behoefde de Indische Regeering in Bantam geen wapengeweld te gebruiken; ongeregelaheden, die uit de onbevredigde eerzucht van ecn of ander Prins of door de kuevelarijen van een ongeschikten $R_{\text {jj }} \mathrm{ksbe-}$ stierder hadden kunnen ontstaan, werden bij tijds voorkomen door de verwijdering der onruststokers.

Slain wij, aan het einde van dit opstel genaderd, een terug-

1 Zie Resoluties van 1 en 29 .Juni m van 7 Aug., de Acte van Investituur van 22 Sipt. eu van der Parra's liapport van 9 October 1753.

$\because$ Zie Resulnties van 20 December 1753, 31 Januari en 25 Februari 1755 , 19 Februari, 14 en 18 Mart en 29 April 1760. 
blik op de hier voor het eerst uit officiëele bescheiden eenigszins uitvoerig behandelde geschiedenis van den grooten Bantamschen opstand in het midden der achtitiende eeuw, dan blijkt daaruit mijns inziens zonneklaar, dat de hoofdoorzaak dezer geweldige beroering gezocht moet worden in het eerzuchtig streven van Ratoe Sjariefa, om het aloude Bantamsche vorstenhuis door een vreemd geslacht te verdringen, maar tevens, dat het vuur des opstauds, hetgeen telkens, schijnbiar gedempt, eensklaps weder ontvlamde, eerst voor goed was uitgedoofd, toen de wettige erfgenaam der kroon op den troon zijner vaderei was hersteld. Daarom wekt het, bij onze tegenwoordige kennis van het toen gebeurde en vau hetgeen later in Bantam voorviel, inderdaad verbazing, dat de kundige de Rovere van Breugel, mar wiens beschouwingen over de toestanden van Bantam in 1786 en 1787 wij reeds herbaaldelijk verwezen, het volgende durfde beweren : "1)ewijl volgens het met den nieuwen Kooning gemaakt contract "het Rijk leenroerig van de Compagnie werd, en de op Ceylon "verbamnen Prins herroepen en tot Kroomprins gemakt wierd, "zuo heeft de Compagnie de beste geleegenheid laten voorbijgaan, "om zonder een druppel bloed te storten, zig het Rịk geheel "en al te onderwerpen, en daardoor meerder magt en aanzien "op het eyland Java te verkrịgen en meerder productie van "Bantam te ontfungen, en eyndelịk de inwoonders selve, welke "onder het juk der alleenheersching hunner despotique Vorsten "zugten, gelukkiger te maakeu. $W_{1 j}$ herhaalen, en deskundigen, "wien de tegenwoordige armoedige staat van Bantam bektnt is, "moeten het met ons instemmen, dat dit het tijdstip was, om "des Compagnies zeetel op Bantam duurzaam te vestigen. Nie"mand had zich tegen 's Compagnies wil verzet, zelfs niet de "nieuw aangestelde Kooning, dien de Kroon, om zoo te spreeken "opgedrongen was, zooals blijkt uit de voorwaarde, waarop hij "deu scepter aanvaard heeft, te weeten, dat zijn neeff, de na "Ceylon gebaunen Prins, opgeroepen en tot Kroonprins verklatard "zou worden, en, zoo hij zelf goedvond, het $k_{\text {!jk }}$ te abdi"ceeren, in zijn plaats den troon beklimmen zoude" 1. Hetgeen van Breugel verder laat volgen over de organisatie van Bantams bestuur, wammeer het geheele Rijk bij 's Compagnies rechtstreeksch gebied gevoegd was, doet thans minder ter zake. De vraag, waar het hier vooral op ankomt, is deze: was het eene wijze en

1 Zie Bijdragen Instituut, N, R, D. I, bl. 114; verg. ook bl. 113. 
voorzichtige statkunde, indien de Indische Regeering in 1752 het Sultansbestuur in Bantain had opgeheven en dit rijk toen reeds geannexeerd had? Na hetgeen hierboven uit de oorspronkelijke stukken is medegedeeld, kan die vraag slechts in ontkennenden zin beantwoord worden. Het verdient dan ook de aandacht, dat van Breugel, die iets verder (bl. 121) zeer te recht den wensch uitspreekt: dat hoofden van gewestelijk bestuur in Indië "zig in naarstigheid oeffenen in het leezen van alle "ter humer Secretary berustende 's Compagnies papieren", en die blịkens zijne beide belangriịke opstellen zelf het Bantamsche archief ijverig had doorzocht, toch na een tijdsverloop van ruim dertig jaar het ware verloop van den Bantamschen opstand niet meer in allen deele kende.

Vooreerst doet hij het teri onrechte voorkomen, alsof de Kroouprins op verzoek van zijn oom uit Ceilon was teruggeroepen. Wel weet hị, dat het dempen van den opstand der Compagnie veel manschappen en groote geldsommen kostte, 1 maar wie deze geschiedenis alleen uit zijue opstelles kent, moet in den waan verkeeren, dat het oproer spoedig na Ratoe Sjariefa's verwịjdering in 1750 gestild was. Wị zagen echter boven, dat de oorlog nog gedurende het geheele jaar 1751 en een deel van 1752 aanhield, en dat de strijd niet alleen plaats had in het eigenlijke rijk van Bantam, maar voor een groot deel gevoerd werd op 's Compagnies eigen erf, de bewesten en bezuiden Batavia gelegen Jakatrasche Beueden- en Bovenlanden, waarbị] de hoofdstad van Neerlandsch-Indië voor een oogenblik zelfs in ernstig gevaar verkeerde. Eindelijk verliest van Breugei, die zijn Indische loopbaan hoofdzakel j.jk als Fiskaal en Administrateur te Bantam doorbracht, geheel uit het oog, welke moeielijkheden de Indische Regeering in hetzelfde tijdvak op Midden-Java te overwimuen had 2. Ook in onze dagen wordt die fout herhaaldelijk

$1 \mathrm{O}_{\mathrm{p}}$ bl. 118 en 119 van ziju opstel geeft van breugel cen uitvoerige specificatie, dat het dempen van den opstand der Compaguie een half millioen guldens kostte.

2 .Jr. Jan de Rovere van Breugel, zoon van den beroemden Advokaat Mr. Johan Festus, werd in 1757 te 's Gravenhage geboren. Hij ging in 1779 als Onderkoopman naar Indië, waar hij het volgende jaar tot Fiskaal en in 1782 tot Administrateur werd benoemd. Daar hij reeds in 1788 repatrieerde, duurde zijn Indische loopbaan betrekkelijk kort. Na zijn terugkeer in het moederland vestigde hij zich te Utrecht, waar bij tot de Bataafsche omwenteling lid der vroedschap was en daarna tot zijn overlijden in 1829 de betrekking ran ontvanger der directe belastingen bekleedde. 
begaan door velen, die, waar zịj terecht inzien, dat de toestanden in een of ander verwijderd deel onzer Oost-Indische berittingen veel te wenschen overlaten, luide klachten aanheffen, dat de Regeering deze of gene Buitenbezitting geheel verwairloost, zouder zich behoorlijk rekenschap te geven, dat een bedachtzaam bestuur, wanneer het in het eene gewest de handen vol heeft, in het overige van den Archipel zooveel mogelijk den status quo moet handhaven. Evenals toch de Indische Regeering zich in onzen tijd door den bloedigen en hardnekkigen zevenjarigen strijd in Atsji verplicht zag, elders een lijdelijke rol te spelen, was in het midden der vorige eeuw een spoedig einde van den Bantamschen opstand vooral daarom zoo hoogst noodzakelijk, omdat men reeds van af 1746 de veel gevaarlijker opstandelingen in het Mataramsche rijk moest bekampen, waar de geheele bevrediging niet voor 1757 tot stand kwam, nadat men eerst de helft des rijks aan Mangkoeboemi als onafhankelijk sultan had afgestaan en daarna ook Maas Sahied, den anderen hoofdopstandeling, onder den titel van Mangkoenegoro tot zelfstandig leenvorst verheven had. Vin Breugels verwijt (bl. 113), dat de kundige Falck nit eigenbat of gemakzucht de Indische Regeering slecht over de Bantamsche zaken had ingelicht, mist elken redelijken grondslag ${ }^{1}$. Had men destijds reeds, in plaats van den wettigen erfgenaam op den troon zijner vaderen te herstellen, de Sultansregeering opgeheven, de opstand zou eindelıos hebben voortgeduurd en in verband met de in MiddenJava opgehoopte gistingstof het Nederlandsch gezag op den rand des verderfs gebracht hebben. T'oen toch zestig jair later de Bantamsche Sultans door Daendels en het Engelsche tusschenbestuur gemediatiseerd werden, en hun tevens elk politiek gezag

1 George Tammo Falek, derde zoon van Otto Willem, Bewindhebber der Oost-Indische Compagnie, en Constantina Margaretha Meinertshagen, zag in 1714 het levenslicht te Utrecht. In 1735 vertrok hij als Onderkoopmau naar Indië en verkreeg in 1743 den raug van koopman, drie jaar later dien van Opperkoopmau. Als zoodanig bestuurde hij de zaken van Bantam in de moeielijke tijden, die wij hierboven schetsten. Met geknakte gezondheid keerde hij in 1752 naar Nederlaud terug, waar hij twee jaar later overleed. Hij was gehuwd met Theodora Adriaua de Crielard, bij we hij vijf kinderen verwekte. Zijn uudste en jungste broeder waren ook in dienst der Compagnie; de eerstgenoemde was de vader van den bekenden Gouverneur van Ceilon, terwijl de Minister Falck een kleiuzoon was van zijn tweeden broeder Anton Reinhard, die in den slag van Rocoux sueuvelde. Zie A. J. van der A a, Biogr. Woordenb. der Nederlanden, aangevuld met genealogische inlichtingen, mij welwillend door den heer Vorstermau vau Oyeu verstrekt. 
ontnomen werd, verwekten deze maatregelen een lange reeks van onlusten, soms van zeer gevaarlijken aard, die tot het midden dezer eeuw hebben voortgeduurd 1.

Met het oug op de toenmalige tijdsomstitudigheden mag dus met recht verklaard worden, dat de Indische Regeering inet veel beleid en doorzicht de beste naatregelen nain, om den geweldigen Bantamschen opstand tot een poedig einde te brengen. Door de nieuwe contracten van 1752 en 1753 werd het tot dusver alleen bondgenootschappelijke rijk Bantam in een leenstaat hervormd, en verkreeg de Compagnie het recht, dit leen zoo noodig vervailen te verklaren. Was het steeds haar staatkunde, zich niet zonder noodzaak te mengen in het inwendig bestuur der aan liaar gezag onderworpen landen, dan waren in Bantam al hare wenschen bevredigd, wamneer dit aan den hoofdzetel van haa. bestuur grenzende rijk in rustige rust verkeerde en zooveel mogelijk producten voor haar monopolie-handel opleverde. Dat dit eerste verlaugen bereikt was, blijkt duidelijk uit het tafereel, dat vall Ossenberch, die in 1755 van Suchteien als Commandeur van Bantam was opgevolgd, bij zijne aftreding schetste in de hierachter volgende Memorie van den staat van Bantam in 1761, dus slechts weinige jaren na het dempen van den opstand. Moest vau Osseuberch diarentegen nog klagen, dat de pepercultuur door verschillende oorzakeu slechte resultaten gaf, ook daariu kwam weldra eene gunstige verandering, toen zijn opvolger Hugo Pieter Faure lang: Bantams westerstraud door de ouder het rechtstreeksch gezag der Compagnie staande vreemdelingen pepertuinen liet aanleggen en in 1763 een geregelde inspectie der inlandsche aanplantingen in de bovenlanden invoerde 2 . De goede uitslag dezer verschillende maatregelen bleek, vooral ouder het uitstekende bestuur van deu Coumandeur Johammes Reynouts, die van 1764 tot 1779 te Bantam het gezag voerde. Het daurop volgende verval der peperteelt, wairover van Breugel herhaaldelijk klaagt, was, behalve ann de algeusene verzwakking van 's Compaguies macht na den noodlottigen Engelschen oorlog, vooral te wijten atan de verarming der Bantamsche landbouwers door de kneveiarijen der grooten en aan de hoe langer hoe meer diuktende heerediensten. Over

1 Zie hierover Veth, Java, I). II, bl. $551-554$ en $579-580$, D. III, bl. $102-104$ en 110.

2 Verǵ. van Breugel, t. a. pl., bl. 134 en 135; ook de Jonge, D. X, bl. 396 . 
het geheel noet bij de beoordeeling van Bantamsche toestanden nooit uit het oog verloren worden, dat dit gewest, ook zonder nog te letten op den voor de volkswelvaart zoo buitengewoon verderfelijken vee-typhus en koort-epidemie van den allerlaatsten tijd, steeds tot de achterlijkste residenties van het eiland Java behoord heeft, terwijl de gouvernements-cultures, zelfs in den bloeitijd van dat stelsel, daar nimmer geslaagd zijn. Bedrieg ik mı niet, dan is deze achterlijkheid van Bantam vooral hieraan te wijten, dat de Arabiiche Sultans van dit rijk, die eerst in den aanvang der zestiende eeuw met een bende Maleische en Javaansche gelukzoekers den westhoek van Java veroverden, nooit eene poging deden, om de door hen overheerschte Soendaneesche bevolking tot hooger outwikkeling optevoeren, zooals reeds eeuwen te voren met zoo gunstigen uitslag door de nịvere en beschaafde Hindoe-kolonisten met de oorspronkelijke bevolking van Midden Java geschied was. Op de Mohammedaansche vorsten van Bantim was diarentegen steeds toepasselijk, hetgeen zoo likwijls van de 'Turken gezegd is, dat ouder de hoeven humner paarden elke grasspruit wegsterft en dat hun bestuur elke bestaande beschaving doodt of het ontluikeu daarvan in de kiem smoort.

In onze algemeene werken van bingralischen aard zoekt men in den regel te vergeefs nar levensbijzonderheden betreflende de ambtenaren en krijgslieden, of zooals het in den stijl dier dagen heette, de civiele en militaire bedienden der Compagnie, die in de achttiende eeuw eene belangrijke plaats in de geschiedenis van Neerlandsch-Iudië bekleedden. Waar Valeutijn ons in den steek laat, wieus groot verzamelwerk alleen nog de eerste twintig jaar dier eeuw omvat, is in gedrukte wer'ken, die men gemakkelijk kan naslaan, bijna niets van dien aard te vinden. Zelfs de door du Bois met veel zorg bewerkte levensbeschrijvingen der Gouverueur-Generaals eindigen met Mossels overlijden in 1761, en van diens opvolgers in de latere jaren dier eenw is alleen het leven van Reinier de Klerk opzeitelijk behandeld in het bekende werk van Huyzers. Wegens deze leente in onze historische literatuur, zoo hinderijk voor ieder, die de geschiedenis van het Nederlandsch gezag in Oost-Indië meer in bijzonderheden wil nagaim, schịnt het mij geen overbodig werk, aan het slot van dit opstel in het kort mede te deelen, wat mij 
bekeud is omtrent den levens'oop van de drie leden der Hooge Regeering, Gollenesse, Loten en van Ossenberch, van wier hand wij hier achter belangrijke regeeringsbescheiden mededeelen.

Voor een deel ben ik daartoe in staat gestaat door de welwillendheid der heeren Obermeyer en Alings, ambtenaren bij het Koloniaal Etablissement te Austerdam, die mij uit de daar bewanrde Dienstrollen vin de Gequalificeerde Bedienden der Compagnie en uit de soldijboeken der naar Indië vertrekkende schepen uittreksels verschaften. Deze voor biografische onderzoekingen onmisbare gegevens bevatten echter lang niet, wat men in onze dagen in een stait van dienst verlangt. Zoo wordt er nooit in vermeid het geboortejaar of de namen der ouders, maar alleen de geboorteplats van den betrokken persoon, het jaar en de betrekking waarin, als ook het schip waarop hij naar Indië vertrok, wanneer hij tot hoogeren rang bevorderd werd, eindelijk het tijdstip, waarop hij door repatrieeren of overlijden den dienst der Compagnie verliet. Evenmin wordt daar opgegeven, in welk deel van Indië hij werkzaam was, tenzij hij tot hoofd van gewestelijk bestuur opklom. Daar echter de Gouverneurs der belangrijkste provinciën in de dagen der Compagnie meestal tevens den titel van Buitengewoon of Gewoon Raad vau Indië voerden, blijkt wederom niet, wanneer zij uit de buitenkintoren naar Batavia terugkeerden en aan de tafel van dat hooge staatslichaam zitting namen. Soms zelfs mist men in deze opgaven uit de Gequalificeerde Rollen de benoetning tot eene of andere aanzieulijke betrekking, terwijl van vele schepen de soldijboeken niet meer aanwezig zijn. In weerwil dezer leemten gaven de bedoelde uittreksels mij een leiddraad, dien ik, zonder al te tijdroovende onderzoekingen in het Rijksarchief in te stellen, uit andere mịj ten dienste staande bromen kon aanvullen tot een beknopte ievenschets, die zonder alles te bevatten, wat uit een geschiedkundig oogpunt van belaug is, toch in ruwe trekken een vrij volledig overzicht geeft van de indische loopbaan der behaudelde personeu.

1)e hier nu volgende drie biografieën bewijzen, evenals de onderscheidene in de aanteekeningen van dit opstel gegeven levensbijzonderheden, hoevele dienaren der Compaguie uit het buitenland afkomstig waren of niet tol de bekende regeeringsfamiliën in ons vaderland behoorden, maar hoofdzakelijk door eigen verdiensten van de laagste betrekkingen tot de hoogste rangen opklommen. $\mathrm{Al}$ is het onloochenbaar, dat er in de vorige eeuw bij benoe- 
mingen tot ambtenaar in Indië dikwijls protectie en concusie plaats greep, waarop zelfs een op ziju pas aan den DirecteurGeneraal geschonken slavimnetje of aan de bedienden der Secretarie van den Stadhouder-Opperbewindhebber ter hand gestelde fooi van invloed kon zijn 1, toch doet men zeer vcrkeerd, door zulke grove misbruiken te zeer als algemeen geldenden regel anu te nemen, daaruit het besluit te trekken, dat destijds de hoogste ambten in Neerlandsch-Indië aan volslagen ongeschikte personen waren toevertrouwd. Natuurlijk was dit nu en dan zoo; het verval en de ondergang der Compagnie sproot echter uit diepere oorzaken. Vooreerst stuitte haar stelsel van monopolie-handel niet alleen de welvaart der adn haar gezig onderworpen inlandsche volkeren, maar het leverde weldra tegenover de steeds toenemende mededinging van andere Europeesche natiën geen noemenswaardige voordeelen meer. Daardoor en door den zich steeds uitbreidenden omslag van 's Compayuies beheer was dit lichaam buiten staat, de sints lang onvoldoende bezoldiging zijner ambtenaren te verhoogen, die dan tot allerlei slechte praktijken hunne toevlucht namen, om zich zelve en hun gezin een onbezorgde toekomst te verzekeren. Wie eens dat verkeerde pad had ingeslagen, deinsde maar al te dikwijls veor niets terug, om groote fortuinen bijeen te schrapen.

Julius Valentijn vin Gollenesse zag volgens de Gequalificeerde Rollen het levenslicht te Grolle. De Mecklenburger Johan Christofle: Wolf, die in het begin van de tweede helft der achttiende eeuw bij de Sekretarie te Taflanapatnam was aangesteld, verhaait echter in zijne reisbeschrijving ${ }^{2}$, dat Gollenesse uit Rostock afkoustig was; inderdaad ligt in het gebied dier stad het riddermatige landgoed Göldenitz met een dorp van denzelfden naam, die

1 Vergelijk de belangrijke mededeelingen van Prof. Naber uit de brivfwisseling van Dr. Petrus Valekenaer, van 1771-1778 Gouverneur der Molukken, aan diens broeder, den vermaarden hoogleeraar (Gids, 1872, D.111, b1. 263 en 265). Zie ook het gewichtig advies, den 18den October 1764 uitgebracht door $\mathrm{N}$ icolaas $\mathrm{H}$ artingh en vier zijner ambtgenooten in den Raad van Indie, over de zoo weuschelijke reorganisatie der Hooge Regeering, waarin onverholen geklaagd wordt. dat de Gouverneur-Generaal, zonder zich in het minste om het oordeel vau deu Raad te bekommeren; "de collegiën en buyten" comptoiren met sijne creatureu en aaubidders voorsiet en alle voordeel gevende "bedieningen met sijue eygen magen, gunstelingen en tributarissen vervult," terwijl de Directeur-Generaal en de verschillende Gouverneurs bij het vergeven der ter huuner beschikking staande betrekkingen eveneens handelden (de fo ng e. D. $X$, bl. 405 .)

2 Wolf, Reise nach Zeilan, Berlin en Stettin, 1782 en 1784, Th. I, s. 179. 
in het Platduitsche dialect dier streken wel Gollenesse zal luiden. Wolf, die omstreeks denzelfden tijd op Ceilon kwam, toen Gollenese dit eiland verliet, kan zich niet geheel vergist hebben, wiar hij dezen een landgenoot noemt. Daar de Compagnie zooveel buitenlanders in dienst nan, was er mijns inziens evenmin reden voor Gollenesse, toen hị in 1723 als sergeant naar Indië vertrok, om een verkeerde geboorteplants op te geven. Waarschijnlijk was dus Gollenesses vader, uit Mecklenburg afkomstig, in Nederlandschen krijgsdienst getreden, en werd hem, toen hij te Groenlo in garnizoen lag, de zoon geboren, wiens Indische loopbaan hier wordt medegedeeld. In 1724 tot Vaandrig bevorderd, werd Gollenesse vijf jaar daarna Luitenant en reeds in 1730 Kapitein. Van zijne verrichtingen in deze militaire rangen is mij niets bekend, maar zijne buitengewoon snelie bevordering mag, zoo al niet aan hooggeplaatste kruiwagens, aan zijne verdiensten als zoodanig worden toegeschreven. In 1732 ging hij over in civelen dienst en werd als Gezaghebber met het bestuur der factorie te Bantam belast. Met hoeveel ijver en en zorg hij deze moeielijke betrekking waarnam, blijkt duidelijk uit de hier medegedeelde, door hem met zooveel talent gestelde Memorie tot Naricht vin zijn opvolger. Daarann was het ongetwijfeld te danken, dat hem in 1734 het Commandement over het vooral vroeger voor de Compagnie veel gewichtiger peperland Malabar werd toevertrouwd. In dit ambt, dat Gollenesse ruim acht jaar bekleedde, beleefde hij zorgelijke tijden, daar hij eerst de zoogenaamde Angriaansche zeeroovers, later het Hindoe-rijk Travankoor moest bestrijden, welke beide oorlogen een hoogst ongunstigen uitslag hadden, en, omdat er in de bestaande geschiedwerken over onze Compagnie bijna niets over te vinden is, hier beknopt moeten worden beschreven.

In het begin der achttiende eeuw had zekere Angria, een opstandeling tegen de heerschappij van den Grooten Mogol, op Dekans Westkust tusschen Bombai en Goa een zeerooverstaat gesticht, die weldra voor de vaart tusschen Hindostan, Perzië en Arabië even gevaarlijk werd, als de Algerijneu den handel in de Middelhndsche Zee onveilig maakten. Reeds in 1707 hadden deze zeeschuimers twee vaartuigen der Compagnie bemachtigd en wilden zij de gevangen schepelingen alleen tegen hoog losgeld vrijiaten. Hoewel de Indische Regeering het volgende jaar a:n hare gewapeude schepen gelastte, hij elke gunstige gelegenheid de Angrianm aan te tasten, was zij buiten 
staat, hun gevoelige nederlagen toe te brengen, en moest zị zelfs bij de Resolutie van 5 September 1715 de treurige verklaring afleggen, dat de uitroeiing van dezen roofstant onuitvoerlijk scheen. Toen echter in 1738 de uit Mokka komende schepen wederom door de Angrianen werden beroofd, besloot de Indische Regeering tot krachtige maatregelen ter humer tuchtiging en gaf aan den kloeken en voortvarenden van Tmhoff, destijds Gouverneur van Ceilon, de opdracht, daartoe met Gollenesse al her noodige te beramen. Maar ook deze expeditie liep zeer ongelukkig af, zoodat de Commandeur van Malabar - zoo diep was 's Comprgnies macht in Voor-Indië reeds gezonken _-. in 174.0 zelfs volmacht verkreeg, om met de zeeroovers een contract van vrede en vriendschap aan te gaan. Uit den aard der zaak kon dit flauwhartig besluit niet met eenigszins bevredi. genden uitsiag bekroond worden. Nog in 1754 leed de Nederlandsche viag een nieuwe nederlaag in deze wateren, toen de naar Suratte uitgezonden schepen Wimmenum en Vrede met de naar Perzië bestemde bark Jakatra eensklaps door de geheele zeerooversvloot werden aangevallen. Na een bloedig en roemrijk gevecht vlogen de beide eerstgenoemde vaartuigen in de lucht, terwijl de opvarenden der geheel reddeloos geschoten en van masten beroofde bark met enkele schipbreukelingen uit de verbrande schepen in handen der Angrianen vielen, die hen gruwelijk mishandelden en tot de zwaarste slavendiensten doemden. In weerwil van dien smaad zon de Indische Regeering alleen op het sluiten van een vredestractaat, terwijl zij tot lossing harer gevangenen de kapitale som van f 22,955 moest uitgeven. Thans echter was de latste ure van den roofstaat geslagen, maar die slag kwam van geheel andere zijde, van de Engelsche Oost-Indische Compagnie, welke jaarlijks vijftig duizend pond sterling ten koste legde, oin hare handelschepen met behoorlijk convooi tegen de zeeschuimers te beveiligen. In Februari 1756 vermeesterde de later zoo beroemd geworden Clive met de vloot van den Admiraal Watson na hardnekkigen strijd de hoofdvesting der Angrianen op het eiland Geria; de indruk dezer overwiming was 700 overweldigend, dat de zeeroovers al humne andere forten op deze doorsneden kust aan de Maratten overgaven. 1 Dit verbazende verschil in krachtsontwikkeling tusschen

1 Zie Resolnties van 26 Ang. 1707, 10 Sept. 1708 en 5 Sept. 1715; 2:5 Sept. eu 27 Oct. 1739,6 Oct. 1739 en 16 Sept. 1740 ; 29 Oct. 1754, 19 
de twee zoo lang op elkander naijverige Oost Indische Compagnieën kan als de voorafschaduwing worden aangemerkt, welke van beide de andere na een halve eeuw geheel uit het sagenrijke Hindostan zou verdringen.

Veel grooter waren nog de beslommeringen, die Gollenesse gedurende zijn bestuur over Malabar ondervond van den toen uitgebroken oorlog met Travankoor, welks vorst zijn aan het zuidwestelijk einde van Dekan gelegen rijk hoe langer hoe meer noordwarts uitbreidde over de kleinere Hindoe-staten, die door hume nabuurschap met Cochin sedert lang in bondgenootschappelijke verhouding tot de Nederianders stonden. Ook was er der Compagnie veel aan gelegen, dat Travankoor de kracht harer wapens zou ondervinden, omdat het monopolie, dat zij tot dusver ongestoord genoten had van de daar geproduceerde peper en gefabriceerde katoenen stoflen, in den laatsten tijd groote inbreuken geleden had, zoo door de Engelschen, die te Anjengo op de kust van Travankoor eene factorie gesticht hadden en ook uit hunne nederzettingen op de kust van Coromandel veel Travankoorsche kleedjes tot zich trokkeu, als door de Franschen, die nu van Mahé uit eene poging deden, om insgelijks vasten voet in Travankoor te verkrijgen. Daar bovendien de altijd doorzettende van Imhoff' er zeer op had aangedrougen, dat de Travankoorsche oorlog met kracht zou gevoerd worden, werd Gollenesse bij Resolutie van 15 September 1;40 tot Admiraal en Veldoverste over deze expeditie benoerrd, en tevens besloten, de kust van Travankoor, om den vorst tot het toestaan der door de Compagnie begeerde vredesvoorwaarden te noodzaken, minstens gedurende twee moessons door een voldoende scheepsmacht te blokkeeren. Aanvankelijk behaalde Gollenesse te land enkele voordeelen, en gelukte het hem, het rijk van Peritally tegen T'ravankoors legermacht te beschermen. I)aar de Indische Regeerung echter omstreeks dezen tijd door den Chineeschen opstand te Batavia en der daaruit ontsproten bloedige: Javaanschen oorlog buiten staat was, de vereischte troepen naar de Vaste Kust aftezenden, ging dit succes te land spoedig weder verloren, en kon men zelfs niet beletten, dat Travankoor het rijk van Koilang overweldigde. Ook de onder Gollenesses leiding staande blokkade der kust van Travankoor had weinig effect, daar bij geen mogelijkheid kon belet worden, dat de Engelschen

Maart, 27 Aug. en 11 Oct. 1756. Verg. ook du Bois, Vies des Gowv. Gen.,

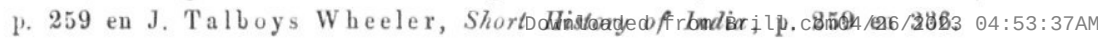


en Fran chen, met welke naties de Compagnie officieel in vrede was, den handel op dit rijk voortzetten. Zoo moest de Indische Regeering reeds bij Resolutie van 9 Juli 1742 aan de Mala. baarsche Ministers de machtiging verleenen, om op welke voorwaarden ook vrede met Travankoor te sluiten. Dewijl echter de vorst van dien stant volstrekt ongeneigd was, naar vredesvoorstellen te luisteren, bleef de oorlogstoestand voortduren, zoodat die last zes jaar later nogmaals herhaald werd. Eindelijk kwam de vrede met Travankoor den $15^{\text {den }}$ Augustus 1753 tot stand, waarbij de Conpagnie van alle verbindtenissen met hare aloude bondgenooten op de Kust van Malabar moest afzien en deze geheel aan de wiliekeur van den oppermachtigen vorst in Travankoor prijs gaf. Wat baatte het bij zulk een smadelijk beding, dat deze vorst aan de Compagnie het monopolie van den lijuwad en peperhandel bleef verzekeren. Nu hare onmacht zoo zonneklaar gebleken was, vereischt het toch geen betoog, dat er op de handhaving van dien voor de inlanders zoo schadelijken alleenhandel hoegenaamd niet te rekeneu uas. Meer nog dan de oorlog met de Angrianen toonde die met Travankoor, hoezeer de eens in Dekan opperwachtige invloed der Nederlandsche Oost-Indische Compagnie gedaald was tot een schaduwbeeld, dat bij den eersten oorlog met eeu der mededingende Europee che natiën als kaf voir den wind verstuiven moest. 1

Reeds in 1742 was Gollenesse van Commauteur op Malabar tot Gouverneur van Ceilon bevorderd. Daar echter dit gouvernement, hetgeen hij negen jaar bestuurde, behaive het eiland Ceilon ook de zoogenaamde Overkust van Madoera en Toetikorin ous. vatte, en de bestuurder dezer belangrijke provincie wegens den verren afstand der hoofdstad van Neerlandsch-1ndie steeds een soort van oppertoezicht hadden over de zoo veel minder uitgebreide Hollandsche bezittingen op de Kusten van Malabar en Coromandel, had Gollenesse ook in rijne nieuwe betrekking nog genoeg met den Travankoorschen oorlog te stellen. Zelfs werd hị bij Resolutie van 1o September 1744 gemachtigd, onder den schijn eener inspectie naar de kust van Madoera een poging te wagen, of het hem mogelijk ware, door een samenkomst met den vorst van Travankoor den vrede tot stand te brengen. ( ) Ceilon zelf was de stand van zaken gedurende Gollenesses

i Zie Resolutics van 15 Sept. 1740 eu 9 Juli 1742 , den over den verwarden toestand vau Malabar zeer uitvoerigen Alg. Brief aan Bewindh. van 8 Januari

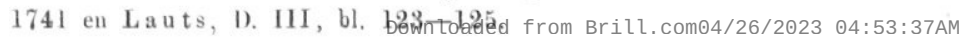


langdurig bestuur veei minder oorlogzuchtig. Wel was de verhouding met den Keizer van Kandi reeds sedert van Imhoff zeer gespannen, en bestond er groote ontevredenheid ouder de kaneelschillers, maar ingevolge den herhaalden aandrang der Indische Regeering wist Gollenesse met veel diplomatiek beleid gevaarlijke uitbarstingeri te voorkomen. De ten deele door Engelsche inblazingen opgestookte Kandische oorlog, waarin onze troepen voor het eerst de hoofdstad van dit binnenlandsche rijk bezetten, en de Gouverneurs Lubbert Jan Baron van Eck en Inan Willem Falck nog eenmaal toonden, dat de Compagnie ook om de West van Indië niet geheel machteloos was, valt dan ook in het later tijdvak van $1760-1766$.

Tegelijk met zijne benoeming tot Gouverneur van Céilon verkreeg Gollenesse den titel van Extraordinair Raad van Indië, en vijf jaar later in 1747 werd hij tot gewoon Raad van Indië bevorderd. Hoezeer men zijne verdiensten op prijs stelde, bleek trouwens daaruit, dat hij, in weerwil zijner verwijdering vin Batavia, na van Imhoff's overlijden door den Raad van Indië den 3den November 1750 werd gekozen, om Mossel als Directeur-Generaal te vervangen, en dat hij in October daaraanvolgende door Bewindhebbers in die hooge en invloedrijke be. trekking werd bevestigd. Eerst in Maart 1751 verliet Gollenesse Ceilon, zoodat hij niet voor den herfst van dat jiar de zittingen van den raad kon bijwonen. Zijn overlijden in 1755 besloot een werkzaam en nuttig leven na een ruim dertigjarigen Indischen dienst. Uit een brief, dien Gollenesse in 1734 uit Bantam aan de Indische Regeering richtte, bleek mij nog, dat hij destijds gehuwd was; de familienaam dier gemalin, waaruit misschien zou blijken, dat zij aan invloedrijke regeeringspersonen vermaagschapt was, bleef mij echter onbekend, evenzeer, of hun echt met kinderen gezegend werd.

Lotens levensloop was reeds eenigszins meer in bijzonderheden bekend door een uit zijn boedel afkomstigen bundel papieren, w:aromtrent Prof. Veth in het Utrechtsch Historisch Genootschap rapport uitbracht 1. Johan Gideon Loten, geboren te Utrecht,

1 Zie Kroniek Hist. Gen., 1860, bl. $107-131$. Hoe belangrijk deze gegevens omtrent Lotens levensloop ook zijn, vindt men er niets omtrent zijne Commissie naar Bantam, terwijl zij ook in andere opzichten bierboven uit de audere mij ten dienste staande bronnen konden worden aangevuld.

4e Volgr. V. 
vertrok in het begin van 1732 naar Indië met den rang van Onderkoopman. Hoezeer zijne familie, voorzoover mij bekend is, niet onder de patricische gerekend wordt, was hị vermaagschapt aan het aanzienlijke geslacht der Hasselaars, dat destijds onder de hooge ambtenaren in Indië en onder de Bewindhebbers herhaaldelijk voorkomt. Daaraan was het waarschijnlijk te danken, dat Loten, nog voor zijne aankomst te Batavia, reeds den $10^{\text {den }}$ Juli werd aangesteld tot de vrij belangrijke betrekking van Fiscaal te Samarang. Alvorens naar zijn nieuwe standplaats te vertrekken, trad Loten den 23sten Augustus, nadat hịj nauwelijks drie weken den bodem van Indië betreden had, in den echt met de nog geen zestienjarige Anna Henrietta van Beaumont. Blijkens haar grafschrift in de oude Hollandsche kerk binnen het fort te Colombo was zij toch den $13^{\text {den November }}$ 1716 aan de Kaap de Goede Hoop geboren en dus waarschijnlijk eene dochter van den daar in 1724 overleden Indepedent.Fiscaal Cornelis vau Beaumont, gesproten uit het bekende patricische geslacht van dien naam. 1 Negen jaar bleef Loten te Samarang, totdat hij in 174l weder naar Batavia vertrok; daar hij waarschijnlijk reeds bij zijn vertrek naar de hoofdplaats van Java's Noordoostkust den rang van Koopman verkreeg, zal hij toen tot Opperkoopman bevorderd zijn. Waar hij in dien rang werkzaam was, is mij onbekend, maar reeds in 1744 vertrok hij als Gouverneur met huisvrouw en eenige dochter naar Makassar, waar hij in het laatst van Maart het bestuur van Adriaan Hendrik Smout overnam. Met veel diplomatiek beleid handhaafde Loten gedurende zes jaar het Nederlandsch gezag tegenover de steeds ourustige Koningen van Boni en Goa en de andere voortdurend op elkander naijverige, bondgenootschappelijke Vorsten, zooals omstandig vermeld wordt in de Memorie tot Naricht, waarbij hij den 17 den October 1750 dit gouvernement aan zijn opvoiger Mr. Cornelis Rosenboom overdroeg. ${ }^{2}$

Loten, die reeds in December 1747 van Bewindhebbers den titel van Extraordinair-Raad van Indië verkregen had, nam bij zijne terugkomst te Batavia terstond deel aan de verkiezing van

1 Zie het curieuse prachtwerk: L. Ludovici, Lapidarium Zeylanicum, being a collection of monumental inscriptions of the Dutch churches and churchyards of Ceylon. Colombo, 1877. 40.

2 Deze Memorie werd reeds in 1853 uitgegeven door Mr. J. A. Grothe met inleiding van Prof. Veth in de Berichten Hist. Gen. te Utrecht, D. V, St. 1, bl. 1-44. 
Mo:sel en Gollenesse tot Gouverneur- en Directeur-Generaal. 1 Ook had hij natuurlijk een werkzaam andeel in de zoo gewichtige beraadslagingen, die de hachelijke stand van zaken, zoo op Midden-Java als in Bantam, gedurende het jaar 1751 in het leven riep, terwijl hierboven uitvoerig is uiteengezet, hoe hij in het begin van het volgende jaar de belangrijke zending a:n het Bantamsche Hof vervulde. Het kan dan ook niet verwonderen, dat de Indische Regeering, toen het Gouvernement van Ceilon weder open viel door het spoedig overlijden van Gollenesses opvolger, Gerard $J_{\text {an }}$ van Vreeland, deze gewichtige betrekking aan Loten opdroeg. Den 30sten September 1752 nam hij daar het bestuur over van den waarnemenden Gouverneur Jacob de Jongh en wist tot zijn vertrek uit Ceilon op 17 Maart 1757 de vrede en rust in dit eiland op even geschikte wijze te handhaven als zijne voorgangers van Imhoff en Gollenesse. Gedurende zịn verblijf op Ceilon werd Loten in October 1754 door Bewindhebbers tot Raad van Indië benoemd. Den $10^{\text {den }}$ Augustus van het volgende jaar verloor hij er zijne echtgenoote, die aldaar begraven werd met hun weinige dagen te voren overleden kleinkind, het zoontje hunner eenige dochter, die met een mij overigens onbekenden van. der Bruggen gehuwd was. 2 Dit verlies droeg waarschijnlijk bij tot Lotens besluit, om naar Nederland terug te keeren, waar hij in Juni 1758 als Admiraal der retourvloot aankwam. Ook was Loten zeer gefortuneerd, daar hij tot aanvulling der geldschaarschte in de openbare kassen van Ceilon 82000 rijksdaalders uit zijne partikuliere geldmiddelen had voorgeschoten, welke som tijdens zijn laatste verblijf te Batavia op verzoek van den Gouverneur-Generaal Mossel tot 100,000 werd aangevuld.

De terugbetaling dezer aan de Compagnie geleende gelden gaf aanleiding, dat Joten zich eenige jaren dairna bij Bewind. hebbers beklangde over de wijze, waarop dit had plaats gehad. Bij dit bezwaarschrift moet ik een oogenblik stilstaan, want terwijl Prof. Veth Lotens verzoek billijk noemt, schijnt het mij na aandachtige lezing van het Request, dat men hier den vinger legt op een dier financieële knoeierijen, waardoor de hoogst geplaatste dienaren der Compagnie maar al te dikwijls de

1 Zie de Jonge, D. X, bl. 162.

2 Misschien Dirk Willem van der Bruggen, in 1746 Onderkoopman en Resident te Rembang. 
belangen van dit handelslichaam benadeelden. 1 Loten erkent zelf, dat de het laatst te Batavia gestorte 18000 rijksdaalders aan zijne gemachtigden aldaar zijn gerestitueerd en door deze met de destijds gewone korting van $7 \frac{9}{13}$ percent ten behoeve der Compagnie aan hem werden overgemaakt. Tevens verzekert hị echter, dat Mossel hem had geguarandeerd, dat de hoofdsom van 82000 rịksdaalders voor altijd op Batavia kon blijven staan, totdat die door hem of van zijnentwege zou worden opgevorderd, en dat de daarop vervallen interest hem steeds rechtstreeks door den Groot-Cassier zonder eenige onkosten zou worden geremitteerd. Dit was dan ook geschied, totdat Mossel op het laatst zijns levens door voortdurende ziekelijkheid niet meer in persoon op de behandeling van zaken kon toezien. Van dat oogenblik af had de Groot-Cassier den interest aan Lotens gemachtigden te Batavia uitbetaald, welke spoedig daarop een aanschrijving der Indische Regeering ontvingen, om Loten te waarschuwen, dat de geheele som zou worden terugbetaald. Dit kapitaal wierd toen na aftrek van $2 \frac{1}{2} \mathrm{pCt}$. provisie-penningen, de bekende korting van $7 \frac{9}{13}$ voor de Compagnie en van $\frac{1}{4} \mathrm{pCt}$. voor den Negotie-Boekhouder aan Loten ter hand gesteld, die nu aan Bewindhebbers verzocht, dat hem deze korting en de interest van 6 pCt. over 18 maanden, van het oogenblik der terugbetaling te Batavia tot de ontvangst van het geld in Nederland, zou worden vergoed. Dat dit verzoek werd afgewezen, komt mij waarlijk niet vreemd voor. Daar de rentestandaard in Indië zooveel hooger is dan in Europa, was het toch een groot nadeel voor de Compagnie en een onbehoorlijk gunstbetoon aan Loten, dat de eerste de op zwaren interest geleende penningen niet kon aflossen, wanneer haar zulks gelegen kwam. De omstandigheid, dat Mossels naar het schijnt alleen mondeling gegeven belofte niet nagekomeu werd, zoodra de Gouverneur-Generaal er niet de hand aan kon houden, bewijst, dunkt mij, dat de Indische Regeering het ook zoo opvatte. Dat Loten met Mossel zeer bevriend was, kwam mij ook in andere opzichten zeer waarschijnlijk voor, terwijl zijn neef, de toenmalige Resident van Cheribon Mr. Pieter Cornelis Hasselaar, den 24sten April 1757 met Mossels dochter in den echt trad. 2

1 Het Request met de eindbeschikking van Bewindhebbers dd. 1 April 1767 is afgedrukt in de Kron. Hist. Gen. te Utrecht, 1860, bl. 116-124.

2 Bij nitzondering, voorzoover de Indische ambtenaren der achttiende eeuw aaugaat, vindt men van dezen Hasselaar een uitvoerig levensbericht in $\mathrm{van}$ der A a, Biogr. Woord. der Nederlanden. 
Kunnen Lotens handelingen in geldelịke aangelegenheden misschien niet in elk opzicht den toets van een nauwkeurig onderzoek doorstaan, blijkens de door hem nagelaten papieren had hij steeds een open oog voor zaken van wetenschap, terwịjl hịj bịj zijn overlijden een belangrijk kabinet van natuurhistorische voorwerpen naliet. Gedurende zijn verblijf te Sama. rang deed hị in J740 een uitstapje naar het binnenland, warop de oudheden van den Oenarang zeer zijne aandacht trokken. Als Gouverneur van Makassar liet hij door den Boekhouder Johan Michiel Aubert een groote kaart van Celebes vervaardigen, die men in de collectie Bodel Nijenhuis aantreft. 1 Ook getuigt het meer voor zịn wetenschappelijken zin dan voor zịn trouw aan de Compagnie, dat hị in 1775 met den beroemden Engelschen hydrograaf Dalrymple in briefwisseling was en dien onderanderen kaarten van Celebes bezorgde. Na zijn terugkeer in Europa deed hij verschillende reizen; zoo was hị blijkens het zooeven aangehaalde Request in 1763 tot herstel van gezondheid in Frankrijk, terwịl hịj jaren daarna nog een tocht deed naar de Kaap de Goede Hoop, waar hịj van Februari 1776 tot Maart van het volgende jaar verbleef, het binnenland bereisde en omtrent deze kolonie en hare bewoners veel bijzonderheden opteekende. Daar Loten deze reis geheel als partikulier ondernam, ligt het vermoeden voor de hand, dat die vooral geschiedde, omdat er op wijlen zijne aan de Kaap geboren gemalin eene erfenis was opengevallen. Loten bereikte een hoogen ouderdom, daar hịj eerst omstreeks 1790 te Utrecht overleed; althaus in dat jaar werden zijne nagelaten zeldzaamheden in die stad verkocht 2.

Willem Hendrik van Ossenberch, wiens levensloop hier nog moet worden medegedeeld, werd te IJperen geboren en vertrok in 1742 als Vaandrig naar Indië. Het jaar daarna werd hị benoemd tot Iuitenant bij de dragonders, die in rustige omstandigheden den Gouverneur-Generaal tot lijfwacht dienden, en reeds in 1744 bị dat korps tot Kapitein, in 1745 tot Ritmeester bevorderd. In dien rang was hij tevens Majoor der

1 In het Rijksarcbief zijn van dezen Aubert nog cen zevental kaarteu van Celebes.

2 Zie Konst- en Lelterbode vau 1790, bl. 34. 
lijfwacht en verzelde als zoodanig den opperlandvoogd van Imhoff op diens belaugrijke reis over Java, die van 24 Maart tot 10 Juni 1746 duurde, en waarbij achtereenvolgens een bezoek gebracht werd, eerst te scheep aan de kantoren te Rembang, Soerabaja, Sumanap, Pasoeroean, Bangkalang en Samarang, en toen over land naar Soerakarta en voorts door de Mataram, Bageleen en Banjoemaas naar Tagal en Cheribon, vanwar men over Krawang te Batavia terugkeerde. ${ }^{1}$ In 1750 verkreeg van Ossenberch den rang van Luitenant-Kolonel en behaalde in den herfst van dat jaar grooten lof door de ffinke wijze, waarop hij de Bageleen van de Javaansche opstandelingen zuiverde. Boven werd reeds omstandig verhaald, welk een roemrijk andeel hij, vonral in den zomer van 1751 , had in de verschillende gevechten tegen de Bantamsche rebellen, en hoe hij in Augustus 1753 aan den Raad van Indië van der Parra op diens zending naar Bantam tot installeering ván den nieuwen Sultan werd toegevoegd.

Veel gewichtiger post werd hem kort daarna bij Resolutie van 30 October 1753 opgedragen, toen hij wegens de ziekte van den wakkeren Gouverneur van Java's Noordoostkust, Johan Andries Baron von Hohendorff, belast werd met de militaire leiding van den nog altijd op Java voortwoedenden oorlog. Hoe. zeer de Indische Regeering van Ossenberch aan het hoofd harer Javaansche legermacht stelde, omdat hij door zijne vorige krijgsverrichtingen bij haar als "een vigilant officier" bekend stond, verkreeg de oorlog, die nu reeds zeven jaar geduurd had, onstreeks dezen tijd een geheel ander karakter, daar de beide voornaamste opstandelingen tegen den Soesoehoenin, Mangkoeboemi en Mangkoenegoro, thans onderling in strijs geraakten. Met meesterlijk beleid trok de Gouverneur-Generaal Mossel van deze omstandigheid partị; in Maart 1754 vertrok hij met den in plaats van von Hohendorff tot Gouverneur van Java benoemden Nicolaas Hartingh naar Samarang, waar ook overeenkomstig van Ossenberchs advies besloten werd, het veroverde gebied krachtig bezet te houden, zonder den vijand telkens op den voet te volgen, maar met ieder der hoofdopstandelingen afzonderlijk onderhandelingen aanteknoopen. Op

1 Het uitvoerig dagregister dezer voor de kennis der binuenlandsche toestanden van Java zoo gewichtige reis zag reeds in 1853 het licht in het eerste deel der door het Instituut uitgegeven Bijdragen, bl. 291-440. 
die wijze kwam reeds in den aanvang van 1755 de vrede met Mangkoeboemi tot stand. Weinige maanden daarna, in Mei van dat jaar, werd van Ossenberch, die nu voor goed in civielen dienst overging, benoemd tot Commandeur van Bantam, tot welks bevrediging hij vier jaar te voren zooveel had bijgedragen. Zes jaar bestuurde hij dit rijk in vrede en rust, totdat hij den 28sten Juli 1761 bij de hier als bijlage opgenomen Memorie het bewind aan zijn opvolger overdroeg, daar Bewindhebbers hem tot loon zijuer aan de Compagnie bewezen diensten tot Extraordinair Raad van Indië benoemd hadden.

Slechts kort bleef van Ossenberch in dien rang te Batavia, daar hij reeds in October door de Indische Regeering geroepen werd, om den in de Javaansche taal en zeden zoo buitengewoon ervaren Hartingh als Gouverneur van Java's Noordoostkust te vervangen. Hoezeer dit uitgebreid en aanzienlijk gouvernement toen in het algemeen bevredigd heeten kon, was daar na de verwoestingen van den nauwelijks geeindigden oorlog nog veel gistingstof opgehoopt, zoodit er voortdurend nauwgeret toezicht en beleid vereischt werd, om te voorkomen, dat het onder de asch smeulende vuur opnieuw in lichte laaie vlam uitbarstte. Telkens ontstonden er toch nieuwe verwikkelingen tusschen den Soesoehoenan en de beide vorsten, waaraan hij een deel van zijn rijk had moeten afstaan, terwijl Mangkoeboemi en Mangkoenegoro nog altijd een hevigen wrok tegeu elkander koesterden. Ook hield Singosari, halve broeder des Sultans, die zijn toevlucht genomen had bij de afstammelingen van den beruchten Soerapati in de feitelijk geheel onafhankelijke bergstreken van Malang, steeds zijn verzet tegen de Compagnie vol en bedreigde aanhoudend de landen van hare leenmamnen, den Soesoehoenan en den Sultan. T'erstond nadat van Ossenberch het bestuur over Java aanvaard had, moest hij zorgen, dat Wiramidja, een andere weerspannige Prins en schoonzoon van Mangkoenegoro, in de onder het rechtstreeksch gezag der Compagnie staande regentschappen Patti, Koedoes en Demak geene verwoestingen aanrichtte, terwijl hem tevens door de Indische Regeering gelast was, met de aan haar ondergeschikte strandregenten de noodige matregelen te beramen tot wering der zeeroovers, die destijds de geheele noordkust van het eiland Java onveilig makteu. Toen van Osseuberch in Mei 1762 de hoven van Solo en Djokjokarta bezocht, deed de Sultan hem het vrecmd verzoek, dat de Compagnie Mangkoene- 
goro van het eiland Java zoude verwijderen. Hoewel de Gouverneur daarop het eenige gepaste antwoord gaf, dat het met dien laatsten Prins in 1757 gesloten contract niet verbroken mocht worden, moest hij evenwel den Sultan beloven, dat hij dieus verlangen aan de Indische Regeering zou overbrengen. Daar ook deze hieraan geen gehoor wilde verleenen, bleef de Sultan in een slechte luim, en had van Ossenberch gedurende zijn bewind de handen vol, om dien vorst van openlijke vijandelijkheden terugtehouden.

In Juni en Juli 1763 deed van Ossenberch een tocht naar Soerabaja, om in persoon den stand van zaken in den onder zijn gouveruement behoorenden Oosthoek optenemen. Ook daar was nog een massa brandstof opgehoopt, want hoezeer de Soesoehoenan reeds bij het contract van $174.3 \mathrm{~J}$ ava beoosten Pasoeroean aan de Compagnie had afgestaan, stonden destijds alleen de strandregentschappen Pasoeroean en Banger (Probolingo) met het daaronder ressorteerende Bezoeki onder haar werkelijk gezag. Malang en Lamadjang waren onder de afstammelingen van Soerapati nog geheel onafhankelijk, evenals het door Balineesche vorsten bestuurde Balamboeang, dat toen behalve de tegenwoordige residentie Banjoewangi ook Panaroekan en Bondowosso omvatte. In het laatst van 1763 had Hendrik Breton, de kundige en voortvarende Gezaghebber van den Oosthoek, uitvoerig betoogd, hoe wenschelijk het was, dat de Compaguie haar gezag ook over deze gewesten vestigde, waartoe thans een schoone gelegenheid bestond, daar een uit Balamboeang verdreven Pangéran hare bescherming had ingeroepen. Van Ossenberch hechtte aan dit voorstel zijne volledige goedkeuring, vooral omdat men daar. door beletten zou, dat de Engelschen, die in deze jaren een drukke vaart door al de wateren van den Archipel onderhielden, daar te eeniger tijd post vatten, in welk geval zij aan den invloed der Compagnie op Java groot nadeel konden berokkenen. De Indische Regeering, die dagelijks meer en meer inzag, dat de ouvang van haar beheer in Azië hare krachten reeds te zeer overtrof, wilde vooralsnog van die machtsuitbreiding niets weten, zoodat in dit opzicht de oude toestand onveranderd was, toen van Ossenberch den 13den Mei 1765 het bewind over Java's Noordoostkust aan zijn opvolger Johannes Vos overdroeg. 1

1 Zie de bij deze gele entheid door van Ossenberch overgeleverde Memorie tot Naricht, medegedeeld doobown. $\mathrm{R}$. W $\mathrm{T}$ a d e ma Berichten Hist Genaglsch. 
Te Batavia teruggekeerd, nam van Ossenberch zitting aan de tafel der Indische Regeering, die hem "wiers bekende ijver "en zorg voor het interest van de Compagnie sy soo dikwijls "gelaudeerd had", kort daarna tot gewoon Raad van Indië verkoos, welke benoeming in October 1767 door Bewindhebbers werd bevestigd. Bij van Osseuberchs ons geblekes overtuiging van het raadzame der ondèrwerping van het nog onafhankelijke Oost-Java mogen wij met rede vooronderstelien, dat zijn advies er veel toe heeft bijgedragen, dat de Indische Regeering op het einde van 1766 aan den Gouverneur Vos de machtiging verstrekte, om Balamboeang te bezetten, hetgeen in de beide volgende jaren door de verovering dezer streken gevolgd werd, hoewel de geheele bevrediging van dit deel van Java eerst in 1777 plaats had, toen de Boegineesche zeeroovers voor goed uit het eiland Noesa Baroeng verdreven werden. Voorts zond de Indische Regeering van Ossenberch in Mei 1768 als Commissaris naar Bantam, om daar den lateren Sultan Alioeddien als Kroonprins te installeeren. Deze zending was hem vooral opgedrageu, omdat hij door zijn vorig bestuur over Bantam aan het Hof zeer bemind was, terwijl hij tevens van deze gelegenheid gebruik makkte, om opnieuw op de bevordering der peperteelt aan te dringen en gerezen verwikkelingen aan de grens van 's Compagnies gebied bewesten de Tangeransche Rivier te beslechten 1. Twee jaar daarna, den 21 sten Juli 1770, overleed van Ossenberch te Batavia, nadat hij der Compagnie gedurende acht en twintig jaar trouw en onafgebroken gediend had en door zijn moed en trouw zooveel tot de bevestiging van haar gezag over het geneele eiland Java had bijgedragen 2 .

De mededeeling dezer korte levenschets scheen mij te eerder gewettigd, omdat dienaangaande niets bekend was , voordat de Jonge in het laatste deel van zijn groot werk veel omtrent van Ossenberch had medegedeeld. De naam van dezen even beleidvollen ambtenaar als dapperen krijgsman was zelfs nagenoeg geheel bij onze vorige geschiedschrijvers van Java verloren gegaan. Hageman noemt van Ossenberch niet, eveumin als diens opvolger Johannes Vos, in zijne lijst der Gouverneurs van Java's Noordoostkust, terwijl

te Utrecht, D. V, St. 2, bl. 178-203; verg. voorts over hem de Jonge, D. X, bl. $196,372,380,386-388$ en $392-395$, dien wij hoofdzakelijk volgden.

1 Zie .1 g. Brief aan Bewindh. van 31 December 1768.

2 Nederl. Postrijder van 1771. 
hij het doet voorkomen, evenals Lauts en op hun voetspoor Prof. Veth, alsof de onderwerping van Malang en de verder oostwaarts liggende streken reeds door Hartingh was beraand en aangevangen, hoezeer deze Gouverneur eene bezetting van dit gebied ten sterkste had ontraden, omdat hij daarin een nadeel voor de Compagnie zag. ${ }^{1}$ Wanneer de door den hoogleeraar Veth zoozeer gewenschte openbaarmaking heeft plaats gehad der officieële bescheiden betrekkelijk de verovering van zuidoostelijk Java van Malang tot Banjoewangi, welke reeds door den verdienstelijken de Jonge bijeenverzameld waren eu door mij in het vervolg van diens werk zullen worden toegelicht en uitgegeven, zal het blijken, hoe deze door van Ossenberch aaubevoleu, voor de geschiedenis van het Nederlandsch gezag op Java zoo belangrijke onderneming onder diens opvolgers Vos en van der Burgh werd uitgevoerd.

3 Zie Hartinghs Memorie van Overgave aan vau Ossenberch bij de Jonge, D. X, bl. 332; Hageman, D. I, bl. 209; Lauts, D. III, bl. 212 en Prof. Veth, D. II, bl. 500. 
Memorie weegens den tegenwoordigen staat en stand der saken aan het Hoff van Bantam, opgesteld door den afgaanden Gesaghebber Jalius Valentein Stein van Gollonesse, om te dienen tot narigt aan synen vervanger, den Opperkoopman Jacob Roman, dd. 28 Aug. 1734.'

Mynheer, nademaalen het Haar Hoog-Edelheedens heeft behaagt volgens Resolutie, in Rade van India genomen op den 23 July jongstleden, my met het Commandoment ter Custe Mallabaar te begunstigen, en UEd. op den 27 daaraanvolgende tot mynen vervanger aan te stellen, met ordre, om ain UEd. agter te laten een duydelyke en distincte Memorie nopens den presenten toestand van saken aan het Bantamsche Hoff met den aankleve van dien; soo heb ik niet willen nalaten, in nakominge van soo dierbaar bevel, aan UEd. te vertoonen, hetgeeue in myn tweejarig bestier van opmerking en angelegenheyd is voorgevallen, en hoedanig sig tegenwoordig de hoffsaken laten aansien, met byvoeging van de noodsakelykste en permanente ordres van Haar Hoog-Edelheedens. Hoewel de dagelykse besigheden en kortheyd des tyds my niet toeiaten, hetselve na behoren te beschaven en in ordre te brengen, sal ik alleen noteeren, hetgeene betrekkelyk is tot den dienst der Ed.Comp., sonder een ampel beschryving van Bantam te maken. Om UEd. hetselve wel te doen begrypen, sal ik een weinig terug moeten treden en UEd. aanwysen, hoedanig het aihier gesteld was ten tyde vau myn komst.

1 Jacob Roman, misschien verwant aan Zacharias Roman, die van 1696 1703 de Bantamsche zaken bestierde, was geboren te Amsterdam, ging in 1721 als Onderkoopman naar Indië en werd in 1730 Koopman. Als zoodanig was hij opperhoofd van het kantoor te Soerabaja, totdat hij met den rang van Opperkoopman tot Gezaghebber van Bantam werd benoemd. Reeds in 1736 verliet hij Banta:ı wegens zijne benoeming tot Boekhouder-Generaal der Hooge Regeering, terwijl hij twee jaar later repatrieerde. 